\title{
Liberal Justices' Reliance on Legislative History: Principle, Strategy, and the Scalia Effect
}

\author{
James J. Brudney ${ }^{\dagger}$
}

Corey Ditslear ${ }^{\dagger \dagger}$

This Article presents a strong case against the conventional wisdom that legislative history is a "politicized" resource, invoked opportunistically by federal judges. The premise that judges regularly rely on legislative history to promote their preferred policy positions-if trueshould find ample support in the majority opinions of liberal Supreme Court Justices construing liberal (pro-employee) labor and civil rights statutes. By analyzing all 320-plus majority opinions in workplace law authored by eight liberal Justices from 1969-2006, the authors establish that legislative history reliance is actually associated with a constraining set of results. When the eight liberal Justices use legislative history as part of their majority reasoning, they do so to justify a higher proportion of their pro-employer outcomes than their pro-employee decisions. The authors explain how liberal Justices use legislative history to illuminate the contours of complex statutory bargains that often favor conservative or pro-employer positions. After considering alternative explanations, the authors conclude that Justices Brennan, Marshall, Souter, Stevens, and others are willing to follow so frequently a legislative history trail leading away from their presumed ideological preferences mainly because they

†Newton D. Baker-Baker \& Hostetler Chair in Law, The Ohio State University Moritz College of Law. t† Assistant Professor of Political Science, University of North Texas. We are grateful to Frank Cross, Phil Frickey, and especially Larry Baum for insightful comments on an earlier draft. Kathy Hall, Hilary March, and Melanie Oberlin furnished valuable research assistance, and Jennifer Pursell provided excellent secretarial support. The Moritz College of Law and its Center for Interdisciplinary Legal Studies contributed generous financial assistance. 
have invoked this interpretive resource in principled fashion. The Article also describes how, in the face of Justice Scalia's fervent opposition to legislative history, liberal Justices since 1986 have opted not to rely on that resource in a series of pro-employer majorities that Scalia joins. One result of the liberals' strategic restraint is that their use of legislative history in the remaining (mostly pro-employee) majority opinions appears more ideological than it was before Scalia joined the Court. Intriguingly, Justice Scalia's strong resistance to legislative history when used by liberal Justices does not extend to majorities authored by his conservative colleagues. Scalia seems prepared to give these conservative colleagues more of a free ride: he is as likely to join their majorities, or vote for their results, when they rely on legislative history as when they do not.

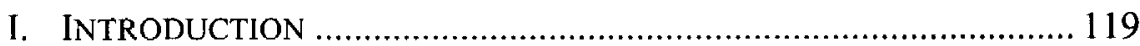

II. THE DEBATE AND THE DATASET ......................................... 123

A. Legislative History as a Politicized Asset?......................... 123

1. Opportunism at the Creation Stage ................................ 123

2. Opportunism at the Interpretation Stage ........................ 125

B. The Dataset of Workplace Law Decisions ........................... 128

III. RESULTS........................................................................... 131

A. Legislative History and Ideology for the Court as a Whole ... 131

1. Legislative History and Ideology Over Time................. 133

2. Legislative History and Ideology in Close Cases ........... 134

B. Legislative History and Ideology for the Liberal Justices ..... 137

1. Ideology and Reliance for Liberal Justices as a Group.... 138

2. Ideology and Reliance for Individual Justices ................ 141

IV. PRINCIPLED AND STRATEGIC USES OF LEGISLATIVE HiSTORY ..... 145

A. Liberal Justices and Principled Reliance on Legislative

History ................................................................. 146

1. Employer Defenses or Immunities............................. 147

2. Compromises Involving Competing Approaches ............ 149

3. Overreaching by Employees ....................................... 151

4. Alternate Explanations Considered............................... 153

5. Interpretive Philosophy .............................................. 157

B. Liberal Justices and Strategic Behavior-A "Scalia Effect".. 160

1. Justice Scalia's Line in the Sand ................................. 161

2. Liberal Justices' Exercise of Legislative History Restraint ............................................................ 163

3. Conservative Justices' Use of Legislative History: A Free Ride? ............................................................ 169

4. Normative Implications of the Scalia Effect ................... 170

V. CONCLUSION ..................................................................... 172 
I.

\section{INTRODUCTION}

Critics of legislative history have long maintained that it lacks neutrality as an interpretive resource. Unlike the dictionary or the canons of construction, committee reports and floor statements are produced by partisans-actors with a stake in the legislative contest to which they are contributing. Legislative history skeptics worry that this political dimension creates a risk of judicial misuse on two levels. Members of Congress or their staffs may craft statements in the legislative record with an eye toward manipulating or misleading judges as to the meaning of text. Moreover, judges reviewing the abundant legislative commentary from bill proponents and opponents may selectively invoke portions of this record to help justify their preferred policy result.

Concerns over the politicized nature of legislative history reliance ${ }^{1}$ have special resonance with respect to federal labor and employment law. Congress's unidirectional legislative goal in the field of workplace law has been to augment employee protections and thereby improve terms and conditions of employment. ${ }^{2}$ From the late 1930 s through the early 1990 s, liberal coalitions in the House and Senate coordinated passage of more than a dozen major employee protection statutes. ${ }^{3}$ Leading members of these

1. Judicial reliance on legislative history has also been criticized as conceptually incoherent (the legislature's intention or purpose is at best deeply muddled and at worst unknowable) and constitutionally inadequate (on separation of powers and legislative supremacy grounds). Those criticisms, which have been discussed elsewhere in some detail, are not addressed in this article. See generally WILLIAM N. ESKRIDGE, JR., DYNAMIC STATUTORY INTERPRETATION 222-24, 230-38 (1994); Abner S. Greene, The Missing Step of Textualism, 74 Fordham L. REv. 1913, 1924-35 (2006); James J. Brudney, Congressional Commentary on Judicial Interpretation of Statutes: Idle Chatter or Telling Response?, 93 MiCH. L. REV. 1, 41-47 (1994).

2. Congress's agenda in the workplace law arena has on occasion departed from this redistributive focus. Provisions in the Taft-Hartley and Landrum Griffin Acts, which restricted employee rights to picket and union rights to impede commerce, reflect congressional intent that was primarily conservative rather than liberal as we are using those terms. Nonetheless, Congress's workplace law statutes have overwhelmingly sided with employees in regulating conflict between employer and employee interests. By contrast, federal legislation in certain other areas-such as securities law or tax law-is less easily classified as liberal or conservative. See, e.g., Margaret V. Sachs, Judge Friendly and the Law of Securities Regulation: The Creation of a Judicial Reputation, 50 SMU L. REV. 777, 784-91 (1997) (discussing the pro-regulation nature of the 1933 Securities Act and 1934 Securities Exchange Act); Michael A. Perrino, Fraud and Federalism: Preempting Private State Securities Fraud Causes of Action, 50 STAN. L. REV. 273, 280-98 (1998) (discussing the anti-regulation nature of the 1995 Private Securities Litigation Reform Act); Bernard Wolfman et al., The Behavior of Justice Douglas in Federal Tax Cases, 122 U. PA. L. REv. 235, 286-89, 320-25 (1973) (analyzing ways in which the pro-regulatory nature of federal tax law is viewed by one Justice as, at times, liberal and, at other times, conservative).

3. These statutes include the National Labor Relations Act and the Fair Labor Standards Act in the 1930s; the Portal-to-Portal Act in the 1940s; the Equal Pay Act, Title VII, and the Age Discrimination in Employment Act in the 1960s; the Occupational Safety and Health Act and the Employee Retirement Income Security Act in the 1970s; the Polygraph Protection Act and the Worker Adjustment Retraining Notification Act in the 1980s; and the Americans with Disabilities Act and 
enacting coalitions were well situated to include statements that purported to explain Congress's specific intentions or general purposes, thereby imbuing key legislative history materials with a liberal spin.

In addition, the Supreme Court has been heavily influenced by liberal Justices since the early 1960s. The voting records of Justices Brennan, Marshall, Stevens, and Souter, among others, reflect a broad tendency to support the legal positions taken by individual employees, racial minorities, women, unions, and retirees-the principal beneficiaries of Congress's employee protection statutes. When authoring majority opinions, these Justices might be inclined to magnify their policy preferences by picking out their friends from among the crowded assortment of statements contained in the legislative record. ${ }^{4}$ Such "friendly" pro-employee statements are likely to be especially visible or salient in the legislative record accompanying workplace law statutes.

In short, the premise that Supreme Court Justices systemically use legislative history to promote or magnify their preferred policy positionsif true-should find ample support in the majority opinions of liberal Justices construing liberal statutes. This Article explores the assumption that liberals on the Court will use legislative history to help justify liberal or pro-employee results significantly more often than they do to support conservative or pro-employer results. It does so by focusing on more than 300 majority opinions in the field of workplace law authored by eight liberal Justices ${ }^{5}$ who have served for at least ten years on the Burger, Rehnquist, or Roberts Courts. Not surprisingly, we found that the eight liberals-Justices Brennan, White, Marshall, Blackmun, Stevens, Souter, Ginsburg, and Breyer-rely on legislative history as a group far more often than their eight conservative counterparts. ${ }^{6}$

More surprisingly, however, we determined that for the eight liberals, the relationship between pro-employee outcomes and legislative history usage is not significant. ${ }^{7}$ If anything, these Justices' legislative history reliance is associated more often with outcomes to which they would likely

Family and Medical Leave Act in the 1990s. Many of these regulatory schemes have been updated and expanded by Congress as additional enactments.

4. See Patricia M. Wald, Some Observations on the Use of Legislative History in the 1981 Supreme Court Term, 68 IOWA L. REV. 195, 214 (1983) (quoting her colleague Judge Leventhal's observation that citing legislative history is akin to "looking over a crowd and picking out your friends").

5. See Part I B., infra, discussing the classification of Justices as liberal or conservative for our purposes, based on the Spaeth Supreme Court database.

6. The eight conservative Justices with at least ten years of service between 1969 and 2006 are Justices Burger, Stewart, Powell, Rehnquist, O'Connor, Kennedy, Scalia, and Thomas. We also discuss conservative Justices' reliance on legislative history in certain settings, in an effort to illuminate or contextualize findings regarding the eight liberals. Our focus, however, is on the liberal Justices and how they make use of the legislative history that accompanies and explains this abundant assortment of pro-employee statutes.

7. We refer here to statistical significance, as described infra at note 48 . 
be ideologically opposed. When liberal Justices use legislative history as part of their majority reasoning, they do so to justify more than half of their pro-employer opinions but just under half of their pro-employee outcomes. Further evidence of this moderating association is that majority opinions authored by liberal Justices reach liberal outcomes $30 \%$ more often than conservative results when not relying on legislative history, but the liberalconservative outcome differential declines to $21 \%$ when the majority opinion's reasoning includes legislative history. A link between legislative history reliance and more moderate outcomes is observable in the aggregated majority opinions of the liberals as a group, and also in the majorities authored individually by Justices Brennan, Marshall, White, Blackmun, Stevens, and Souter.

On the other hand, we found that since 1985, this moderating association has waned among the cohort of liberal Justices. During his final years on the Court, Justice White-who had previously relied on legislative history disproportionately to help justify pro-employer results-invoked legislative history in only rare instances. In addition, the two most recently appointed liberals, Justices Ginsburg and Breyer, have reached proemployee results in majorities that rely on legislative history substantially more often than in majorities that do not. Our data for the eight conservative Justices shows that these Justices increasingly rely on legislative history to support their preferred policy outcomes. Use of legislative history by the "older" conservatives-Justices Burger, Stewart, and Powell-is linked to more liberal or pro-employee results; this, again, is a distinctly moderating association, also observable in the pre-1986 majorities authored by Justice Rehnquist. By contrast, legislative history reliance by two of the "newer" conservatives-Justices O'Connor and Kennedy-is strongly associated with results favorable to employers. ${ }^{8}$

We thus have uncovered evidence to suggest that both principle and politics may be at work in the way the liberal Justices rely on legislative history, and we examine some implications of both sets of findings. With respect to the role of principle, a key question is why legislative history accompanying liberal, pro-employee statutes is used so often by liberal Justices to support conservative, pro-employer outcomes. Based on a review of some sixty pro-employer majority opinions authored by the liberal group of Justices, we have identified three categories of legislative history regularly invoked to defend conservative interpretations of these essentially pro-employee laws.

8. Two other newer conservatives, Justices Scalia and Thomas, virtually never rely on legislative history when writing majority opinions. Their occasional reliance on legislative history in dissents is associated with pro-employer results. The two newest conservatives, Chief Justice Roberts and Justice Alito, have not been on the Court long enough to allow for detailed analyses regarding their legislative history reliance. 
First, liberal Justices use legislative history to amplify or unpack the meaning of employer defenses or exemptions built into a statute. Second, the liberals rely on legislative history to establish the existence or details of a compromise on the issue being reviewed. Finally, they use legislative history to demonstrate that the legal position identified with employees and their supporters has overreached in its claims.

In our view, the liberal Justices' repeated use of these three categories to explain pro-employer outcomes reveals judicial use of legislative history to be deliberative and coherent in important ways that legislative history skeptics have not adequately recognized. We consider possible alternative explanations for the moderating tilt associated with liberals' legislative history usage, including the impact of majority opinion assignments and the prospect that liberals may be pursuing complex strategic motives when they use legislative history in these settings. Although such factors may play a supplemental role, we conclude that they do not detract from the importance of the three principled categories.

With regard to the possible role of politics, an important inquiry is why both liberal and conservative Justices after 1985 have relied on legislative history more often to justify or explain what would seem to be their preferred policy results. We suggest two ways in which Justice Scalia's fervently expressed opposition to legislative history as an interpretive resource may have shifted the institutional dynamic for legislative history usage by stimulating strategic behavior on the part of some of his colleagues. This "Scalia Effect" may make other Justices appear more ideological in their approach to legislative history, primarily because of the circumstances in which liberals opt not to invoke the resource, although also because of when conservative Justices choose to use it.

First, liberal Justices who wish to secure Justice Scalia's unqualified support have declined to invoke legislative history in a subset of more than twenty pro-employer majority opinions that he has joined. It is striking that for three-fifths of these pro-employer majorities eschewing legislative history, the winning party's briefs include-and often feature prominently-legislative history arguments. By not resorting to readily available legislative history justifications, liberal Justices may be ensuring Justice Scalia's full endorsement for these decisions; the remaining majorities that do rely on legislative history consequently take on a more distinctly pro-employee complexion.

Second, conservative Justices aware of Justice Scalia's outspoken resistance may confine their use of legislative history, invoking it primarily to anticipate or counter legislative history arguments advanced by liberal Justices in dissent. Virtually every non-unanimous majority opinion favoring employers in which a conservative Justice relies on legislative history also includes legislative history reliance by a dissenting liberal Justice. Justice Scalia joins all but one of these pro-employer majorities, 
suggesting he may be giving his conservative colleagues a free ride on their use of legislative history in these circumstances.

Part I summarizes the current debate over whether legislative history is inherently unreliable because of its political nature. Part I also identifies the dataset we use to examine the Supreme Court's use of legislative history. Part II presents our central findings regarding the ideological tenor of legislative history usage by the Court as a whole, by the liberal cohort of Justices, and by the liberal Justices individually. Part III pursues key aspects of our findings in doctrinal and behavioral terms, analyzing certain illustrative majority opinions and invoking social science and institutional perspectives on how the Court operates.

II.

THE DEBATE AND THE DATASET

\section{A. Legislative History as a Politicized Asset?}

\section{Opportunism at the Creation Stage}

Pivotal players in the lawmaking process-congressional staff and lobbyists as well as Senators and Representatives-recognize that judges are willing to rely on legislative history materials as an aid to construing statutory text. Such materials are produced by a relatively small number of participants, who operate outside the more formal and costly processes required for the enactment of statutory language. ${ }^{9}$ In this setting, concerns have arisen that legislative history will too often include explanations or assertions supporting a policy outcome that was not addressed, achieved, or even attainable in the text itself. ${ }^{10}$

Legal academics and judges describing such public choice-related concerns refer to two troubling institutional features of legislative history creation. One is that congressional committees-the source of the most influential legislative history - tend to be preference outliers. Their reports advance general positions and specific constructions that are more extreme or less balanced than what a hypothetical median legislator would believe to be contained in the accompanying text. ${ }^{11}$ The other is that congressional

9. See generally Brudney, supra note 1, at 21-26 (discussing opportunity costs within the legislative process, notably the constraints on time and political capital that limit Congress's ability to enact new laws).

10. See Kent Greenawalt, Statutory Interpretation: 20 Questions 181 (1999); John F. Manning, Textualism as a Nondelegation Doctrine, 97 COLUM. L. REV. 673, 687-88 (1997).

11. See generally William N. Eskridge, JR., Philip P. Frickey \& Elizabeth Garrett, LEGISLATION AND STATUTORY INTERPRETATION 311 (2d ed. 2006) [hereinafter ESKRIDGE ET AL.]. See also William N. Eskridge, Jr., The New Textualism, 37 UCLA L. REV. 621, 643-44 (1990) (discussing possible strategic planting of legislative history by the House committee chair with regard to the Endangered Species Act); Barry Weingast \& William J. Marshall, The Industrial Organization of 
staffers-the authors of virtually all legislative history-understand that members rarely read the committee or floor commentaries drafted by their underlings. Accordingly, staffers can revel in the "heady feeling" 12 that stems from having subtly altered the meaning of textual arrangements previously negotiated by the legislators. ${ }^{13}$

The public choice account of opportunistic behavior by the key producers of legislative history has not gone unchallenged. Some scholars suggest that committee-approved legislation generally reflects the policy preferences of the chamber as a whole, ${ }^{14}$ and others contend that committee actors are adequately constrained by whistleblowing and its related consequences. ${ }^{15}$ Members know they must depend on colleagues' representations at the committee stage because the accuracy of committeebased information is integral to moving Congress's agenda. Moreover, as repeat players with long-term reputational interests, committee leaders know that their statements about a bill's specific or general objectives will be monitored by minority committee members and also by the chamber majority. ${ }^{16}$

As for the role of staff, it may be more reasonable to view them primarily as faithful agents implementing their bosses' directives. Congressional staff are recruited and hired for their congruence of viewpoints and loyalty as well as for their expertise and judgment, and they will therefore typically reflect or reinforce their member's positions and values. ${ }^{17}$ Further, considerations of political accountability, sharpened by

Congress; or Why Legislators, Like Firms, Are Not Organized as Markets, 96 J. POL. ECON. 132, 14852 (1988) (discussing committee members as significantly more likely than an average Senator or Representative to support the interest groups active within committee's jurisdiction).

12. Blanchard v. Bergeron, 489 U.S. 87, 99 (1989) (Scalia, J., concurring). See also In re Sinclair, 870 F. 2d 1340, 1345 (7th Cir. 1989) (Easterbrook, J., speculating on a staffer's role in manipulation of legislative history).

13. See generally ESKRIDGE ET AL., supra note 11, at 311; Nicholas S. Zeppos, Legislative History and the Interpretation of Statutes: Toward a Fact-Finding Model of Statutory Interpretation, 76 VA. L. REV. 1295, 1310 (1990).

14. See, e.g., Keith Krehbiel \& Douglas Rivers, The Analysis of Committee Power: An Application to Senate Voting on the Minimum Wage, 32 AM. J. POL. SCI. 1151, 1168 (1988); Thomas W. Gilligan \& Keith Krehbiel, Organization of Informative Committees by a Rational Legislature, 34 AM. J. POL. SCI. 531, 557-58 (1990); Forest Maltzman, Maintaining Congressional Committees: Sources of Member Support, 23 LEGIS. STUD. Q. 197, 201, 210-12 (1998).

15. See generally GREENAWALT, supra note 10 , at 182 .

16. See ESKRIDGE ET AL., supra note 11, at 311. See also WALTER J. Oleszek, Congressional PROCEDURES AND THE POLICY PROCESS 106 ( $7^{\text {th }}$ ed. 2007) (describing committee reports as "directed primarily at House and Senate members" and as "the principal official means of communicating a committee decision to the entire chamber").

17. See, e.g., Barbara S. Romzek \& Jennifer A. Utter, Congressional Legislative Staff: Political Professionals or Clerks?, 41 AM. J. POL. SCI. 1251, 1259, 1265-66, 1268-71 (1997); Susan Webb Hammond, Recent Research on Legislative Staffs, 21 LEGIS. STUD. Q. 543, 545-46, 570 (1996); HARRISON W. FoX, JR. \& SuSAN WEbB Hammond, CONGRESSIONAL STAFFs 148, 153 (1977); David E. Price, Professionals and "Enterpreneurs": Staff Orientations and Policy Making on Three Senate Committees, 33 J. POL. 316, 320-25 (1971). 
the prospect of embarrassing media coverage, effectively encourage diligence by members when overseeing staff performance.

Still, even absent evidence of widespread abuse, skeptics worry that the known fact of judicial reliance on legislative history subjects courts to deception. One appellate jurist has opined that legislators are in effect "encouraged to salt the legislative record with unilateral interpretations of statutory provisions they were unable to persuade their colleagues to accept." 18 Another has referred to legislative history as "clues [that] are slanted, drafted by the staff and perhaps by private interest groups." 19

These worries arguably take on added weight with respect to the field of labor and employment law. From the New Deal onward, the House and Senate labor committees have been more internally partisan than many other committees, and labor committee composition has often been to the left of the median member. ${ }^{20}$ These committees have generated a series of major employee protection bills: some were enacted essentially as reported by the committee although others underwent modifications on the floor. ${ }^{21}$ It has been suggested that the legislative histories accompanying at least some of these bills did not match the policy inclinations or judgments of the chamber as a whole. ${ }^{22}$

If key liberal committee members and their staffs have been successful in reshaping the legislative record to support their own preferences, one might anticipate that pro-employee explanations or elaborations would be reflected in Supreme Court decisions invoking that record. We examine this preliminary hypothesis-that the Court's overall reliance on legislative history is associated with liberal results-in Tables 1 and 2 below.

\section{Opportunism at the Interpretation Stage}

The concerns expressed above portray judges as unsuspecting victims, prone to be misled by the deceptive slant of a legislative record. Of course, Supreme Court Justices are not generally viewed as such naïve or

18. Int'l Bhd. of Elec. Workers Local 474 v. N.L.R.B., 814 F.2d 697, 717 (D.C. Cir. 1987) (Buckley, J., concurring).

19. Frank H. Easterbrook, Text, History, and Structure in Statutory Interpretation, 17 HARV. J. L. \& PUB. POL'Y 61, 61 (1994)

20. See generally Richard F. Fenno Jr., CONGRESSMEN IN COMMITTEES, 62, 74, 78, 83-84, 158, 169-70, 234-42 (1973); John Londregan \& James M. Snyder, Jr., Comparing Committee and Floor Preferences, 19 LEGIS. STUD. Q. 233, 243, 249 (1994).

21. For examples of major provisions created in the course of floor debate, see Title I of LMRDA (Senate floor); sex discrimination prohibitions of Title VII (House floor).

22. See, e.g., William N. Eskridge, Jr., Reneging on History? Playing the Court/Congress/President Civil Rights Game, 79 CAL L. Rev. 613, 644-49, 657-58 (1991); Daniel B. Rodriguez \& Barry R. Weingast, The Positive Political Theory of Legislative History: New Perspectives on the 1964 Civil Rights Act and its Interpretation, 151 U. PA. L. REV. 1417, 1474-98 (2003). See generally LEE EPSTEIN \& JACK KNIGHT, THE CHOICES JUSTICES MAKE 154-56 (1998) (discussing distinct position of congressional committees with respect to civil rights policy preferences during 1970s). 
inexperienced figures. They are nominated and confirmed based on their considerable background as judges, lawyers, or policymakers, as well as on their articulated judicial philosophies. This experience is thought to generate both doctrinal sophistication and a fairly developed set of ideological predispositions. One might therefore expect that Justices whose backgrounds indicate an identification with the positions of employees, unions, or civil rights claimants would themselves be favorably inclined, even if subconsciously, toward a legislative record supportive of those groups. Conversely, one might assume that Justices whose experiences suggest alignment with employers and the business community would have less enthusiasm for invoking a legislative record tilted toward employee interests, or would sift that record for evidence supporting employers' legal positions.

This leads into a second area of concern about legislative history as a political asset: that it provides judges the opportunity to engage in strategic behavior. Statutes are typically the result of legislative bargaining, and a prevailing coalition will include members whose support for the final bill language reflects differing priorities and even distinct objectives. The plethora of legislative record materials produced by coalition members (including staff, interested private parties, and perhaps executive branch personnel) is likely to express a nuanced range of perspectives as to what the proposed law is meant to accomplish.

Subsequently, judges exercising interpretive discretion may invoke this legislative history in ways that favor the priorities of some coalition members over others, or even that prefer positions espoused by members outside the coalition. ${ }^{23}$ Their stated rationale for such exercises of discretion would likely be that the history supports what the judges believe to be the better-reasoned legal position. But legislative history skeptics fear that what is selected as persuasive evidence will tend to comport with a judge's own preferred policy outcome, and that such an accommodation is too readily secured given the choices available to judges from a richly diverse legislative record. ${ }^{24}$

Legislative history proponents have responded to concerns that judges engage - consciously or not-in such strategic behavior. There is a broadly recognized hierarchy of legislative history sources that operates as an initial constraint on judicial discretion. Conference reports, standing committee reports, and explanatory floor statements by bill managers or sponsors are clustered near the top in terms of their presumptively persuasive force, while legislative inaction, statements by nonlegislative drafters, and post-

23. See Frank H. Easterbrook, What Does Legislative History Tell Us?, 66 CHI-KENT L. REV. 44I, 447 (1990).

24. See Greenawalt, supra note 10, at 181; Alex Kozinski, Should Reading Legislative History Be an Impeachable Offense? 31 SUFFOLK U. L. REV. 807, 813 (1998). 
enactment history are arrayed close to the bottom. ${ }^{25}$ Beyond these guidelines, judges are effectively pressured to consider on a case-by-case basis whether the legislative record materials are sufficiently accessible, relevant, and reliable to be construed as convincing evidence of what Congress understood it was approving. ${ }^{26}$ In deciding such matters, and in defending their decisions against dissenting colleagues, judges generally explain that certain statements should sensibly be construed as part of a broader understanding among legislators, based on the identity of the speaker, the nature and visibility of her presentation, or the reasoned elaboration contained in her remarks. ${ }^{27}$ These factors vary from one setting to the next, just as there are context-specific variations in the applicability of dictionary definitions or language canons.

Nonetheless, some regard these constraints that channel interpretive discretion as incapable of controlling judges who inevitably bring their own normative vantage points to a legislative record replete with both aspiration and self-promotion. Skeptics point to the frequency with which majority and dissenting opinions at the Supreme Court disagree as to the meaning of legislative history. ${ }^{28}$ In the labor and employment law area, where Congress has regularly acted to enhance employee protections, but where the scope of those protections is not always clear, disagreements between liberal and conservative Justices are common.

One of the most controversial examples can be seen in Steelworkers $v$. Weber, ${ }^{29}$ in which Justices Brennan and Rehnquist adopted radically different viewpoints as to whether the Congress that enacted Title VII of the 1964 Civil Rights Act meant to prohibit voluntary affirmative action plans. The Brennan majority opinion determined that committee reports and floor debate revealed an intent to avoid regulating voluntary efforts to redress glaring racial imbalance in a workforce. ${ }^{30}$ The Rehnquist dissent insisted in over twenty-five pages that the law's chief sponsors and supporters could not have been clearer in identifying all such race-conscious plans as prohibited. $^{31}$

25. See ESKRIDGE ET AL., supra note 11, at 310-317; GREENAWALT, supra note 10, at 173-175.

26. See ESKRIDGE ET AL., supra note 11, at 304, 310; Brudney, supra note 1, at 75-82.

27. See Charles Tiefer, The Reconceptualization of Legislative History in the Supreme Court, 2000 WIS. L. REV. 205, 230-32 (2000) (discussing the common sense approach of imputing institutional intent); William N. ESKRIDGE, JR., PHILIP P. Frickey \& EliZabeth Garrett, CaSES aNd Materials ON LEGISLATION 981-82, 1000-01, 1020-21 (4th ed. 2007) (discussing the hierarchy of legislative history resources in Supreme Court decisions based on which legislative record evidence is likely to be viewed as authoritative among reasonably attentive congressional colleagues)

28. See generally ADRIAN VERMEULE, JUdGING UNDER UNCERTAINTY 89-115 (2006); Kozinski, supra note 24 , at $817-19$ (pointing out areas where the courts may differ in the interpretation and use of legislative history).

29. 443 U.S. 193 (1979).

30. Id. at 202-08.

31. Id. at 229-54. 
The majority's use of legislative history in Weber has been viewed as an illustration of how liberal Justices can make the record say what they want it to, ${ }^{32}$ but there are less-prominent instances of analogous disagreements. When reviewing the history of a liberal workplace statute, conservative Justices authoring pro-employer dissents have construed specific legislative record statements to mean the exact opposite of what the liberal majority has stated that they mean. ${ }^{33}$ Pro-employer dissents also have relied on a separate piece of legislative record evidence than the ones invoked by the liberal majority, ${ }^{34}$ and they have concluded that portions of the same record reveal an overarching purpose at odds with the evidence of specific intent discussed by the liberal majority. ${ }^{35}$

If these decisions are representative, one would expect liberal Justices' legislative history reliance in workplace law to be associated with liberal pro-employee results substantially more often than with conservative proemployer outcomes. We examine this central hypothesis and related questions in Tables 3 through 6 below, based on Supreme Court workplace law decisions over thirty-seven years.

\section{B. The Dataset of Workplace Law Decisions}

Our dataset consists of every Supreme Court case with a published merits opinion addressing some aspect of the employment relationship, from the start of the Burger Court in fall 1969 through the 2005-06 term. ${ }^{36}$ This universe features 578 decisions that implicate one or more federal statutes or, in rare instances, matters of federal common law. ${ }^{37}$ The

32. See, e.g., Rodriguez \& Weingast, supra note 22 , at 1517-21.

33. See Sch. Bd. of Nassau Cty v. Arline, 480 U.S. 273, 292-93 (1987) (Rehnquist, J., dissenting from Justice Brennan's majority opinion construing section 504 of the Rehabilitation Act).

34. See Gen. Dynamics Land Sys. Inc. v. Cline, 540 U.S. 581, 606 (2004) (Thomas, J., dissenting from Justice Souter's majority opinion construing the Age Discrimination in Employment Act).

35. See Complete Auto Transit Inc. v. Reis, 451 U.S. 401, 426-28 (1981) (Burger, C.J., dissenting from Justice Brennan's opinion construing the Labor Management Relations Act).

36. For a detailed discussion of how we assembled our dataset, see James J. Brudney \& Corey Ditslear, Canons of Construction and the Elusive Quest for Neutral Reasoning, 58 VAND. L. REV. 1, 1529 (2005). The complete dataset and codebook are available on the web at http://www.psci.unt.edu/Ditslear/LHdata.htm.

37. The dataset through the first term of the Roberts Court consists of 658 decisions altogether, including 80 presenting issues of constitutional law that do not implicate federal statutes. Although we have included these "pure" constitutional decisions as a distinct category in other articles making use of the dataset, we omit them here. The content and function of "constitutional history" (e.g., convention proceedings, The Federalist Papers, state ratification debates) have been analyzed differently from legislative history by certain current Justices and also by legal scholars. See, e.g., William N. Eskridge, Jr., Should the Court Read the Federalist but Not Statutary Legislative History?, 66 GEO. WASH. L. REV. 1301 (1998); Note: Justice Scalia's Use of Sources in Statutory and Constitutional Interpretation: How Congress Always Loses, 1990 DuKE L. J. 160 (1990). We determined that these differences, along with the Court's relatively infrequent reliance on constitutional history (roughly $10 \%$ of the 80 cases, compared with over $40 \%$ reliance on legislative history for the 578 statutory cases) warranted excluding the pure constitutional decisions from our analysis in this setting. 
decisions address not only well-trodden fields such as union-management relations and race or gender discrimination, but also a wide range of other subject areas including safety and health, minimum wage and overtime standards, retirement benefits, discrimination based on age or disability, and even employment-related disputes arising in connection with tax, criminal, or immigration law. Workplace law cases have formed a reasonably stable portion of the Court's docket since the mid 1970s, about one-sixth of all merits decisions when calculated at three-year intervals. ${ }^{38}$

We focus here on the Court's use of legislative history as an interpretive resource to help explain or justify its decisions. The Supreme Court ordinarily relies on committee reports, floor debates, hearings, and other legislative record evidence for one of two reasons: to help resolve textual ambiguity, or to confirm and reinforce apparent plain meaning. ${ }^{39}$ The Court makes regular use of other interpretive resources as well, such as the plain meaning of statutory language, the Court's own precedent, the canons of construction, and agency deference. We do not attempt to prioritize among the various resources typically cited as helpful in contributing to the Court's result. ${ }^{40}$ Judicial reasoning is highly situationspecific, and any effort to rank the Court's multiple and often complementary justifications for its holdings would simply be too subjective. For our purposes, so long as legislative history is expressly identified and discussed by the majority as either an affirmatively probative or a determining factor, we conclude that it was relied upon by the Court. ${ }^{41}$

In order to address the concern that legislative history is more of a political than a neutral interpretive resource, we consider in some detail the relationship between the Court's reliance on legislative history and the ideological direction of its majority opinions. We have classified all 578 decisions based on whether the Court's outcome favored unions or

38. To limit the effects of yearly fluctuations in the Supreme Court's workplace law caseload, we compared the number of cases for three-year periods.

39. See generally Brudney, supra note 1, at $42 \mathrm{n} .172$ and sources cited therein. The Court on occasion invokes legislative history for a third reason-to assist in avoiding an absurd or unconstitutional result. See, e.g., NLRB v. The Catholic Bishop of Chi., 440 U.S. 490, 504-06 (1979).

40. Apart from legislative history, we have coded for nine other interpretive resources on which the Justices rely with some frequency: (i) the plain or ordinary meaning of text, (ii) dictionaries, (iii) language canons, (iv) legislative purpose, (v) legislative inaction, (vi) Supreme Court precedent, (viii) common law precedent, (viii) substantive canons, and (ix) agency deference. The Court's opinions almost always rely on at least two resources, and the vast majority recognize three or more.

41. When a majority opinion invokes legislative history only in a deflecting way, i.e., to dismiss the value ascribed to it by a lower court, a party's brief, or a dissenting Justice, we do not regard this as positive reliance. Our conclusion that such deflecting references are not integral to the majority's affirmative reasoning process rests on our decision to distinguish between substantive uses of an interpretive resource that an opinion's author supports and substantive uses the author rejects as unpersuasive, inconclusive, or incorrect. Moreover, to examine most clearly the relationship between judicial reasoning and judicial outcomes, we chose to analyze resources as they are used to advance results endorsed by the majority. See generally Brudney \& Ditslear, supra note 36, at 25-26. 
employees (liberal) as opposed to employers (conservative). ${ }^{42}$ In addition, we have identified each of the twenty-one Justices who served during this period as either liberal or conservative.

In identifying the ideological orientation of the Justices, we relied on voting scores derived from a database compiled by Professor Harold Spaeth, a well-recognized scholar of Supreme Court voting behavior. ${ }^{43}$ By combining a number of Spaeth's designated issue areas, we are able to provide a distinctively formulated subject matter field that is comparable to our own workplace law dataset. ${ }^{44}$ Based on the voting scores for these issue areas, we identify eleven Justices as conservative and ten as liberal. ${ }^{45}$

42. For about $8 \%$ of the 578 cases (forty-four total), we were unable to identify the Court's decision as liberal or conservative. These involved either decisions that were closely divided in outcome between employees and employers, or disputes between individual employees and their unions where the direct policy implications seemed to us too close to call (e.g., allowing a newly elected union president to discharge appointed business agents who had opposed him in the election, or disciplining an individual for crossing a picket line during a strike authorized by a majority of the employees when the individual's conduct violates the union constitution). We coded "reverse discrimination" cases (such as United Steelworkers of Am. v. Weber, 443 U.S. 193 (1979)) as liberal if the outcome favored the group or class that was the primary intended beneficiary of the statutory provision. For further discussion of our ideological coding of cases, see Brudney, supra note 36, at 18-19.

43. See The Original U.S. Supreme Court Judicial Database, 1953-2005 terms (last updated 1010-2006) http://www.as.uky.edu/polisci/ulmerproject/sctdata.htm. See generally JEFFREY A. SEGAL \& HAROLD J. SPAETH, THE SUPREME COURT AND THE ATTITUDinAL MODEL app. 6.1, at 255-60 (1993).

In recent years, political scientists have been experimenting with alternative ways of operationalizing judicial ideology over time, using more sophisticated statistical methods. See, e.g., Andrew D. Martin \& Kevin M. Quinn, Dynamic Ideal Point Estimation via Markov Chain Monte Carlo for the U.S. Supreme Court, 1953-1999, 10 POL. ANALYSIS 134 (2002); Michael Bailey \& Kelly H. Chang, Comparing Presidents, Senators, and Justices: Interinstitutional Preference Estimation, 17 J.L. ECON. \& ORG. 477 (2001). These measures, however, are derived through the original Spaeth dataset, relying on vote scores that are still used regularly in the political science field. We chose not to pursue the newer measures, which are generally oriented toward the universe of all cases rather than a discrete subset of decisions. We do take account of the changing nature of legislative history reliance over time, as well as changes in the approaches taken by individual Justices. See infra tbls. 1-6 and accompanying discussion.

44. We obtain an ideology score exogenous to our dataset based on each Justice's votes through the 2005-2006 term (including votes before the 1969 term for eight of the twenty-one) on a subgroup of issues in the Spaeth data base. These consist of all civil rights issues (Issue variable codes in 200 s and 300 s), all union-related issues (Issue variable codes 553 to 599), selected government employee and federal preemption issues (Issue variable codes 432, 435, 503, and 910), and selected economic issues (Issue variable codes $601,605,611,621,631$, and 636). The civil rights issues are modestly overinclusive in that they contain cases dealing with voting rights, education, and general poverty law as well as cmployment. The combined issue codes are also mildly underinclusive in that certain omitted codes represent policy areas (for example, First Amendment) that contain some employment-related subjects. Still, the Spaeth combination of issue codes has substantial overlap with our employmentbased dataset, and in screening out a number of potentially distorting or conflating policy areas (such as criminal law, judicial power, and natural resources), it provides a distinctive assessment for the ideological orientations of the Justices.

45. Justices are coded as liberal or conservative by using simple directional analyses keyed to the proportion of liberal votes in the Spaeth Issue areas. The eleven conservatives (Justices Harlan, Stewart, Burger, Powell, O'Connor, Scalia, Kennedy, Thomas, Rehnquist, Roberts, and Alito) voted for individuals (against employer, business, or government-related positions) less than $50 \%$ of the time; the other ten Justices cast pro-individual employee votes in more than $50 \%$ of the cases. When relying on judicial classifications in our analyses, we focus on the eight liberals (Justices Brennan, Marshall, White, 
The Spaeth combination of issue codes provides a useful independent baseline; at the same time, there is a close correlation between voting behavior in our dataset and in the larger Spaeth collection of civil rightsunions-economic-government employee issues. ${ }^{46}$

III.

RESULTS

\section{A. Legislative History and Ideology for the Court as a Whole}

Preliminarily, we reviewed ideological outcomes in general for our dataset and found that the decisions over this thirty-seven year period are fairly evenly divided. There is a slight tilt toward results favoring

Blackmun, Stevens, Souter, Ginsburg, and Breyer) and the eight conservatives (those listed above except for Harlan, Roberts, and Alito) who served ten or more terms between 1969 and 2006.

46. The voting scores listed below reflect the percentage of cases in which a Justice cast votes favoring the legal position of individuals, employees, or unions; a score above $50 \%$ is characterized as liberal. We present vote scores based on the Spaeth Issue codes side-by-side with scores based on our own dataset; we include in parentheses the number of ideologically-identified votes cast by each Justice.

$\begin{array}{lll} & \text { Spaeth Issue Codes } & \text { Brudney \& Ditslear } \\ \text { Marshall } & 78.6 \%(1154) & 76.3 \%(423) \\ \text { Brennan } & 77.2 \%(1611) & 74.9 \%(408) \\ \text { Breyer } & 68.6 \%(261) & 70.0 \%(139) \\ \text { Ginsburg } & 66.8 \%(286) & 63.2 \%(155) \\ \text { Souter } & 64.2 \%(385) & 63.8 \%(196) \\ \text { Stevens } & 61.7 \%(1115) & 64.4 \%(514) \\ \text { Blackmun } & 58.8 \%(1141) & 62.1 \%(450) \\ \text { White } & 57.6 \%(1511) & 51.8 \%(454) \\ \text { Stewart } & 48.5 \%(1109) & 46.9 \%(201) \\ \text { O'Connor } & 42.8 \%(796) & 46.3 \%(395) \\ \text { Kennedy } & 42.2 \%(476) & 46.3 \%(242) \\ \text { Powell } & 41.3 \%(779) & 40.9 \%(307) \\ \text { Burger } & 39.5 \%(911) & 37.4 \%(319) \\ \text { Scalia } & 34.6 \%(544) & 40.7 \%(290) \\ \text { Rehnquist } & 30.6 \%(1293) & 37.7 \%(570) \\ \text { Thomas } & 27.7 \%(343) & 41.4 \%(174) \\ \text { Douglas } & 86.3 \%(946) & 78.9 \%(78) \\ \text { Black } & 75.7 \%(723) & 71.4 \%(21) \\ \text { Harlan } & 45.5 \%(626) & 47.6 \%(21) \\ \text { Roberts } & 36.8 \%(19) & 62.5 \%(8) \\ \text { Alito } & 30.0 \%(10) & 40.0 \%(5)\end{array}$

For twelve of the sixteen Justices with ten terms or more on the Court, there is less than a $5 \%$ difference between our voting scores and Spaeth's scores. For three Justices (White, Scalia, and Rehnquist) the difference is between $6 \%$ and $10 \%$, and for one Justice (Thomas) it is $14 \%$. Only one of the twenty-one Justices has a differential that changes his characterization: Justice Roberts' Spaeth "label" (conservative) is at odds with his voting record in our dataset based on eight workplace law cases in his initial term. 
employees; of the 534 cases for which we coded directional outcomes, 282 $(53 \%)$ were liberal decisions while $252(47 \%)$ were conservative. ${ }^{47}$ Employees and unions did fare somewhat better when appearing before the Burger Court than they have since 1986 in the Rehnquist and Roberts Courts; the difference in employee success rates between the two eras approaches statistical significance. ${ }^{48}$

This finding of broad-based ideological neutrality with a liberal tilt, although seemingly at odds with the Court's more conservative reputation in recent decades, could be explained by several different factors. As a threshold matter, disputes that are litigated all the way to the Supreme Court are likely to raise reasonable legal arguments on both sides, and the win rates of employee and employer advocates may therefore tend to be comparable over an extended period. ${ }^{49}$ Further, in the area of labor and employment law the business community in recent decades has played a larger role in presenting the Justices with cases that push the envelope than it did during the Warren Court era or the early Burger Court years. To the extent that employers have pursued an ambitious agenda before a Court they view as relatively sympathetic, their win-loss rate may have suffered as a consequence. ${ }^{50}$

Finally, aggregate results keyed simply to outcomes cannot measure the magnitude or consequences of particular Supreme Court decisions. An employer win in a major substantive case and an employer loss in a minor jurisdictional case may carry very different policy implications that our initial quantitative analysis does not capture. With respect to the Justices' use of legislative history, we attempt to account for this magnitude factor by examining results in close cases as a separate category, and also by reviewing illustrative decisions in doctrinal terms.

47. We classified forty-four of the 578 cases as indeterminate. See supra note 42 . In nineteen of the 578 cases (nine in the Burger Court and ten in the Rehnquist Court), the Court announced its holding and set forth its principal reasoning in a plurality opinion. We treat these plurality opinions as majorities for purposes of our analyses.

48. In the Burger era, $56 \%$ of decisions were liberal while in the Rehnquist and Roberts eras it has been $50 \%$; the difference approaches significance $(t=.0875)$. The use of "significant" refers to results that are statistically significant using either the t-test or the z-test, as appropriate, based on the sample size. A t-test compares the mean of two data set samples, controlling for the sample size, to determine whether the difference between the statistics could be due to chance. A result that is significant at the .05 level ( $\mathrm{t} \leqq .05$ ) has no more than a $5 \%$ chance of occurring purely as coincidence. R. MARK SIRKIN, STATISTICS FOR THE SOCIAL SCIENCES 178-89 (1995). We follow the common social science approach of designating results with a t-value between .05 and .10 as "approaching significance." All statistical analyses in this Article are run using Stata Version 8.

49. See generally George L. Priest \& Benjamin Klein, Reexamining the Selection Hypothesis: Learning from Wittman's Mistakes, 14 J. LEGAL STUD. 215, 218-19 (1985); Richard A. Posner, Legal Formalism, Legal Realism, and the Interpretation of Statutes and the Constitution, 37 CASE W. RES. L. REV. 179, 190-91 (1987).

50. Conversely, the employee rights community's inclination to pursue new approaches before the Court has been more subdued in recent decades. See generally Lee Epstein, Interest Group Litigation During the Rehnquist Court Era, 9 J. LAW \& POLITICs 639, 681-82 (1993). 


\section{Legislative History and Ideology Over Time}

We begin by reporting the extent to which the Court as a whole has relied on legislative history to justify its liberal (pro-employee) and conservative (pro-employer) holdings. Table 1 presents legislative history reliance as a proportion of the 282 liberal decisions, the forty-four cases with indeterminate outcomes, and the 252 conservative decisions reached from 1969 to 2006 . Table 1 includes a similar breakdown for cases decided during the two basic eras that constitute this thirty-seven year period: the 301 workplace law decisions issued by the Burger Court over seventeen terms through June 1986, and the 277 workplace law cases resolved by the Rehnquist and Roberts Courts in twenty terms through June 2006. ${ }^{51}$

\section{Table 1: Ideological Direction of Legislative History (LH) Reliance Over Time ( $\mathbf{N}=578)$}

\begin{tabular}{|l|c|c|c|}
\hline \multicolumn{1}{|c|}{ Result } & $\begin{array}{c}\text { Percentage of All } \\
\text { Cases } \\
\text { Relying on } \\
\text { LH (N=578) }\end{array}$ & $\begin{array}{c}\text { Percentage of } \\
\text { Burger Court } \\
\text { Cases Relying on } \\
\text { LH (N=301) }\end{array}$ & $\begin{array}{c}\text { Percentage of } \\
\text { Rehnquist/Roberts } \\
\text { Court Cases Relying } \\
\text { on LH (N=277) }\end{array}$ \\
\hline Liberal & $43.6 \%(282)$ & $53.9 \%(152)$ & $31.5 \%(130)$ \\
\hline Indeterminate & $36.4 \%(44)$ & $39.3 \%(28)$ & $31.3 \%(16)$ \\
\hline Conservative & $41.7 \%(252)$ & $52.9 \%(121)$ & $31.3 \%(131)$ \\
\hline
\end{tabular}

The findings set forth in Table 1 indicate that the Court relies on legislative history to justify conservative results about as often as liberal outcomes. For the universe of all 578 cases, the difference between legislative history's contribution to decisions that favor employees $(43.6 \%)$ as opposed to employers $(41.7 \%)$ is not close to significant. Further, although Table 1 suggests that overall reliance on legislative history has declined sharply from the Burger to the Rehnquist/Roberts eras, ${ }^{52}$ that decline has not been accompanied by a change in the ideological direction associated with legislative history reliance. The Burger Court invoked legislative history a shade more often to help support liberal as opposed to conservative results $(53.9 \%$ to $52.9 \%)$ and the Court in its reliance since 1986 has established a comparably bare margin favoring liberal outcomes $(31.5 \%$ to $31.3 \%)$.

51. There are fewer workplace law decisions per term during the Rehnquist/Roberts era (13.9) than in the Burger era (17.7). This decrease parallels the overall decline in number of decisions per term for the period since 1986. See generally LEE EPSTEIN ET AL., THE SUPREME COURT COMPENDIUM: DATA, DeCISIONS \& DEVELOPMENTS $82-84$ tbl. 2-11 (3d ed. 2003).

52. See also James J. Brudney \& Corey Ditslear, The Decline and Fall of Legislative History? Patterns of Supreme Court Reliance in The Burger and Rehnquist Eras, 89 JUDICATURE 220, 222 (2006) (reporting a significant decrease in legislative history reliance between the Burger and Rehnquist eras). 
With respect to the 244 decisions (out of 578) that rely on legislative history, there is a more noticeable liberal tilt: $50 \%$ reach pro-employee results, $43 \%$ have pro-employer outcomes, and $7 \%$ are indeterminate. ${ }^{53}$ This liberal slant is observable in Burger Court decisions relying on legislative history, although not in decisions during the Rehnquist/Roberts Court. $^{54}$ The difference should not be surprising given that, as noted earlier, employees and unions enjoyed somewhat more favorable results overall during the Burger era than they have experienced since $1986 .{ }^{55}$ Importantly for our purposes, the ideological complexion of cases relying on legislative history in each era does not differ significantly from the complexion of cases in each era that do not invoke legislative history. ${ }^{56}$

\section{Legislative History and Ideology in Close Cases}

A substantial number of Supreme Court decisions are closely contested among the Justices and feature one or more reasoned dissents. In Table 2, we examine whether close cases that include majority reliance on legislative history have a distinct policy orientation. We do so by reviewing the ideological outcomes associated with two subsets of majority opinions that invoke legislative history: majorities in unanimous cases (involving zero dissenters) and in close cases (involving a vote margin of one or two). The results reported in Table 2 indicate that a comparable proportion of liberal and conservative unanimous decisions invoke legislative history. ${ }^{57}$ At the same time, close cases relying on legislative history are more likely to reach liberal rather than conservative results. ${ }^{58}$

53. This distribution favors employees slightly more than the ratios for the 334 decisions that fail to invoke legislative history, but the difference is not significant. Considering all 578 decisions, $49 \%$ reach liberal results, $44 \%$ have conservative outcomes, and $8 \%$ are indeterminate. Percentages exceed 100 due to upward rounding for each of these three figures.

54. From 1969 to 1986 , the Court's 157 decisions relying on legislative history reached liberal results in $52 \%$ of the cases and conservative outcomes in $41 \%$. The Rehnquist/Roberts Court's eightyseven decisions relying on legislative history were split down the middle- $47 \%$ reached a pro-employee result and $47 \%$ a pro-employer outcome.

55. See supra note 48 and accompanying text.

56. In the Burger Court, the 144 decisions not relying on legislative history reached pro-employee results $49 \%$ of the time and pro-employer results $40 \%$ of the time. In the period since 1986, the 190 decisions not relying on legislative history reached liberal and conservative results with the same frequency $-47 \%$ of the time. These findings virtually mirror the results for decisions relying on legislative history, reported at supra note 54.

57. The left-hand column of findings reflects that $33.5 \%$ of the 158 unanimous liberal decisions relied on legislative history, while $36.4 \%$ of the seventy-seven unanimous conservative decisions invoked this interpretive resource. For purposes of classifying vote margins, we counted concurring opinions on the side of the majority. An opinion that both concurred and dissented was counted as a dissent.

58. For the difference on close cases, $t=.0855$. In all tables, we identify significant differences with two asterisks $\left({ }^{* *}\right)$ and differences that approach significance with one asterisk $\left(^{*}\right)$. See supra note 48. In addition to the results for close and unanimous decisions reported in Table 2 , we also coded results for the 108 decisions involving a wide margin of support (a vote differential of five, six, or seven) and the ninety-seven cases involving support by a moderate-sized majority (a vote margin of 


\section{Table 2: Ideological Direction of Legislative History (LH) Reliance in Close and Unanimous Cases $(\mathbf{N}=373)^{59}$}

\begin{tabular}{|c|c|c|}
\hline Result & $\begin{array}{c}\text { Percentage of Unanimous } \\
\text { Cases Relying on LH } \\
(\mathrm{N}=\mathbf{2 4 8})\end{array}$ & $\begin{array}{l}\text { Percentage of Close } \\
\text { Cases* Relying on } \mathrm{LH} \\
(\mathrm{N}=125)\end{array}$ \\
\hline Liberal & $33.5 \%(158)$ & $59.2 \%(49)$ \\
\hline Indeterminate & $30.8 \% \quad(13)$ & $45.5 \%(11)$ \\
\hline Conservative & $36.4 \% \quad(77)$ & $46.2 \%(65)$ \\
\hline
\end{tabular}

It is noteworthy that our 125 close cases have a distinctly conservative or pro-employer direction overall $(52 \%$ conservative -65 of 125 -versus $39 \%$ liberal -49 of 125), a direction that is strikingly evident in developments since 1986. Close cases during the Burger era were evenly divided between liberal and conservative outcomes, but the Rehnquist/Roberts Courts' close decisions have favored employers twice as often as employees. ${ }^{60}$ This conservative shift may in turn reflect the cumulative impact of partisan nominations. Eleven of the thirteen Justices who joined the Court since 1970 were chosen by Republican presidents, and almost every one of the eleven was more conservative than the Justice he or she replaced. ${ }^{61}$ It makes sense that a closely divided Court would tend to tip in a pro-employer direction as the proportion of more conservative replacements increases. ${ }^{62}$

three or four). For both sets of cases, majorities relying on legislative history are somewhat more likely to reach liberal rather than conservative results. The difference is not significant for the moderatemargin cases, but approaches significance $(t=.071)$ for the wide-margin decisions. Copies of these results are available from the authors.

59. Our $\mathrm{N}$ of 373 consists of 248 unanimous decisions (thirteen of which are indeterminate) and 125 close cases (eleven of which are indeterminate).

60. Of seventy-one close decisions in the Burger era, thirty-two favored employers, thirty-two favored employees, and seven were indeterminate. By contrast, of fifty-four close cases since 1986, thirty-three favored employers, only seventeen favored employees, and four were indeterminate.

61. The individual replacements chosen by Republican presidents were as follows: Blackmun for Fortas; Rehnquist and Powell for Harlan and Black; Stevens for Douglas; O'Connor for Stewart; Scalia for Burger; Kennedy for Powell; Souter for Brennan; Thomas for Marshall; Roberts for Rehnquist; and Alito for O'Connor. Except for Kennedy (who is only slightly more liberal than Powell) and Roberts (who has served only one term through June 2006), each new Justice scores more conservative on the Spaeth scale than the Justice being replaced. See supra note 46.

62. Unlike close cases, our 248 unanimous decisions have a decidedly liberal slant both before and after 1986. In the Burger era, $68 \%$ of 108 unanimous decisions reached pro-employee or liberal results while $26 \%$ established pro-employer conservative holdings. During the Rehnquist/Roberts years, $61 \%$ of 140 unanimous decisions have been liberal while $35 \%$ have reached conservative outcomes. This prolonged tendency for unanimous cases to produce liberal results may be part of a broader institutional dialogue involving perceptions of an increasingly conservative Court. Lower courts 
Of greater relevance to this study is the fact that when the majority relies on legislative history in close cases it is more likely to reach a liberal rather than a conservative outcome. This result too reflects sharp differences in cases decided since 1986. During the Burger era, majority opinions relied on legislative history to help justify closely divided conservative decisions as often as they did to help explain liberal results. ${ }^{63}$ By contrast, close cases in the Rehnquist and Roberts years have relied on legislative history to support pro-employee results at twice the rate of reliance for pro-employer outcomes. ${ }^{64}$

The Justices' performance in close cases where legislative history is used reveals striking differences between the votes of the eight long-serving liberal Justices and the votes of their conservative counterparts. Liberal Justices as a group are more likely to rely on legislative history than are conservatives. We suggest below that this difference has more to do with interpretive philosophy than ideological orientation. ${ }^{65}$ When the Court is closely divided, it is not surprising that Justices who author majority opinions reaching pro-employee results tend to be liberal and therefore heavier legislative history users, while Justices who author decisions favoring employers are likely to be conservative, hence lighter legislative history users.

In addition, however, the four conservative Justices with extended tenure on the Rehnquist but not Burger Courts (Justices O'Connor, Scalia, Kennedy, and Thomas) have relied on legislative history significantly less often than did their three conservative colleagues (Justices Stewart, Burger, and Powell) who served primarily or exclusively on the Burger Court. ${ }^{66}$

anticipating the Supreme Court's direction, and pro-employer litigants enthused about where the Court seems to be heading, may tend to expect and argue for more rapid conservative movement in the workplace law arena than the Court is prepared to undertake. The Justices' response to such pressures is a unanimous rebuff. The liberal tilt of unanimous decisions also may be due in part to conservative Justices feeling more constrained by rule-of-law norms than do their liberal counterparts, and therefore more often voting to uphold legal positions that diverge from their own policy preferences. See Saul Brenner \& Theodore S. Arrington, Unanimous Decision Making on the U.S. Supreme Court: Case Stimuli and Judicial Attitudes, 9 POL. BEHAV. 75, 78-80 (1987) (speculating on conservative Justices' penchant for rule-of-law norms during Vinson, Warren, and Burger Courts). Finally, unanimous decisions may reflect more opportunistic judgments by conservative Justices: if the cases raise issues that are less important in policy terms or are less intensely ideological, liberal victories can be ceded at a relatively small cost.

63. For close cases reaching pro-employer results in the Burger years, legislative history reliance was $66 \%$ ( 21 of 32 decisions); for close pro-employee cases, legislative history reliance was $62.5 \%$ (20 of 32 decisions).

64. During the Rehnquist/Roberts era, legislative history reliance in close liberal cases has been 53 $\%$ ( 9 of 17 decisions) but for close conservative cases it has been a mere $27 \%$ ( 9 of 33 decisions). This difference is significant $(\mathrm{t}=.038)$.

65. See Part IIIA.5 infra.

66. The four new conservatives identified in text have relied on legislative history in 22 of 113 (19.5\%) majority opinions. The three old conservatives relied on legislative history in thirty-five of sixty-eight $(51.5 \%)$ majority opinions. The difference is significant $(t=.0001)$. Justice Powell served briefly on the Rehnquist Court and Justice O'Connor for a short period on the Burger Court, but each 
This difference between new and old conservatives has meant that close cases favoring employers after 1986 have been less likely to invoke legislative history as part of majority reasoning than was true before 1986. The distinction between new and old conservatives has sharpened the differences in legislative history reliance that exist between liberal and conservative Justices more generally.

Before turning to relationships between legislative history and ideology for individual Justices, we note that during the Rehnquist/Roberts era, majority authors of unanimous decisions rely on legislative history substantially less often than they do for close cases. ${ }^{67}$ This lower level of legislative history reliance in unanimous opinions raises the possibility that liberal Justices may be choosing to invoke legislative history less often when Justice Scalia is on their side (in unanimous cases where they write the opinion) than when he opposes their position (in close cases where they author what is usually a pro-employee majority opinion). We pursue this and other implications of a potential Scalia Effect in Part III. ${ }^{68}$

\section{B. Legislative History and Ideology for the Liberal Justices}

Thus far, we have found that legislative history reliance by the Court as a whole is not distinctly ideological. Legislative history is as likely to be invoked to help support pro-employee results as pro-employer outcomes, and this Court-wide neutrality applies for both the Burger Court and the Rehnquist and Roberts years. There are, however, certain changes in the ideological tenor of legislative history usage between the two eras. Close cases decided since 1986 that rely on legislative history are significantly

authored about $90 \%$ of their majority opinions in workplace law during the period to which we have assigned them. Justice Rehnquist, who served for more than a decade on each Court and authored a substantial number of majorities in each period, is not included in this comparison.

67. The 140 unanimous majority opinions issued in the Rehnquist/Roberts era rely on legislative history $26 \%$ of the time. By contrast, the fifty-four majority opinions in close cases during these years rely on legislative history $35 \%$ of the time. This difference between legislative history usage in unanimous and close cases is not significant, although it is not far off $(t=.115)$. Overall, $31 \%$ of the 277 Rehnquist/Roberts Court majorities rely on legislative history.

For the dataset as a whole, legislative history is significantly more likely to be used in close cases than in unanimous decisions $(t=.001)$, and this difference in usage also is significant during the Burger years ( $t$ $=.008$ ). The fact that legislative history was used so heavily in Burger era close cases, and that these close cases were evenly divided between liberal and conservative outcomes (see supra note 63), suggests a consensus view that evidence of congressional intent was especially valuable in closely contested settings. No such consensus has existed since Justice Scalia joined the Court. See Part IIIB infra.

68. While $33 \%$ of forty-nine pro-employer unanimous decisions authored since 1986 rely on legislative history, only $22 \%$ of eighty-five pro-employee unanimous decisions during this period invoke legislative history to help support the holding. However, the $22 \%$ figure is attributable to the approaches taken by the five conservative Justices in this period. The liberal Justices rely on legislative history in $31 \%$ of their unanimous pro-employee opinions (seventeen of fifty-four); by contrast, Justices Rehnquist, O'Connor, Kennedy, Scalia, and Thomas invoke legislative history in a mere $7 \%$ of their pro-employee unanimous majorities (two of twenty-eight). See infra Part III.B for further discussion. 
more likely to reach liberal results, although this was not true with respect to close cases during the Burger years. Further, legislative history during the Rehnquist and Roberts years is invoked substantially less often in unanimous decisions than in close cases.

We now shift our attention to patterns of legislative history usage by the Court's liberal Justices. Our central hypothesis was that the eight liberals would likely rely disproportionately on legislative history to support a pro-employee agenda. If this hypothesis is correct, we should expect to "unmask" the Court's overall ideologically neutral approach by focusing on the liberal cohort of Justices. As indicated below, however, the evidence does not support our core assumption.

\section{Ideology and Reliance for Liberal Justices as a Group}

We consider whether the use of legislative history is ideologically linked in the hands of our eight liberal Justices by assessing reliance over the entire thirty-seven year period and also over the separate Burger and Rehnquist /Roberts eras. We begin by focusing on the 162 majority opinions authored by these Justices that relied on legislative history, to determine the extent to which-when using this resource-liberal Justices are explaining or justifying liberal, pro-employee outcomes.

\section{Table 3: Outcomes Associated with Legislative History (LH) Reliance by Liberal Justices}

\begin{tabular}{|c|c|c|c|c|c|c|}
\hline & \multicolumn{2}{|c|}{ All Cases } & \multicolumn{2}{|c|}{ Burger Court } & \multicolumn{2}{|c|}{$\begin{array}{l}\text { Rehnquist/Roberts } \\
\text { Court }\end{array}$} \\
\hline & $\begin{array}{c}\text { Liberal } \\
\text { Decisions }\end{array}$ & $\begin{array}{l}\text { Conserv. } \\
\text { Decisions }\end{array}$ & $\begin{array}{c}\text { Liberal } \\
\text { Decisions }\end{array}$ & $\begin{array}{l}\text { Conserv. } \\
\text { Decisions }\end{array}$ & $\begin{array}{c}\text { Liberal } \\
\text { Decisions }\end{array}$ & $\begin{array}{l}\text { Conserv. } \\
\text { Decisions }\end{array}$ \\
\hline $\begin{array}{l}\text { Percentage } \\
\text { of Decisions } \\
\text { Relying on } \\
\text { LH }\end{array}$ & $\begin{array}{c}48.7 \% \\
(189)\end{array}$ & $\begin{array}{l}54.2 \% \\
(107)\end{array}$ & $\begin{array}{l}55.6 \% \\
(99)\end{array}$ & $\begin{array}{c}62.9 \% \\
(62)\end{array}$ & $\begin{array}{c}41.1 \% \\
(90)\end{array}$ & $\begin{array}{l}42.2 \% \\
(45)\end{array}$ \\
\hline
\end{tabular}

Table 3 indicates that liberal Justices as a group are outcome neutral when they rely on legislative history. If anything, their pattern of reliance in majority opinions is slightly at odds with our assumption that they will use legislative history to favor a pro-employee approach.

As one would expect, our eight liberal Justices author majority opinions that uphold employee legal arguments substantially more often than they vindicate employer positions. Out of 322 authored majorities, the liberal Justices have supported pro-employee results in $59 \%$ of the cases 
(189 decisions) and pro-employer outcomes in 33\% (107 decisions). ${ }^{69}$ This heavy preponderance exists for majorities authored both before and after 1986. ${ }^{70}$

More surprising is that for liberal Justices, legislative history usage points away from the pro-employee purposes of the workplace law statutes. Liberal Justices use legislative history to help support pro-employer outcomes somewhat more often (in $54.2 \%$ of their conservative majority opinions) than pro-employee results (in $48.7 \%$ of their liberal majority opinions). This slight moderating tendency exists in both the Burger and the Rehnquist/Roberts eras. The differences reported in Table 3 are not significant, but the fact that liberal Justices' reliance on the legislative history of liberal workplace statutes even tilts in such a pro-employer direction warrants further examination.

The pro-employer shading reported in Table 3 becomes somewhat more pronounced when we compare outcomes for the liberal Justices in the 162 decisions they authored that rely on legislative history versus the 160 decisions that do not.

\section{Table 4: Comparing Liberal Justices' Majorities that Rely and Do Not Rely on Legislative History (LH)}

\begin{tabular}{|l|r|r|r|r|r|r|}
\hline & \multicolumn{2}{|c|}{ All Cases } & \multicolumn{2}{c|}{ Burger Court } & \multicolumn{2}{c|}{$\begin{array}{c}\text { Rehnquist/Roberts } \\
\text { Court }\end{array}$} \\
\hline & $\begin{array}{c}\text { Liberal } \\
\text { Decisions }\end{array}$ & $\begin{array}{c}\text { Conserv. } \\
\text { Decisions }\end{array}$ & $\begin{array}{c}\text { Liberal } \\
\text { Decisions }\end{array}$ & $\begin{array}{c}\text { Conserv. } \\
\text { Decisions }\end{array}$ & $\begin{array}{c}\text { Liberal } \\
\text { Decisions }\end{array}$ & $\begin{array}{c}\text { Conserv. } \\
\text { Decisions }\end{array}$ \\
\hline $\begin{array}{l}\text { LH } \\
\text { Reliance } \\
(\%)\end{array}$ & 57 & 36 & 54 & 38 & 62 & 32 \\
\hline $\begin{array}{l}\text { No LH } \\
\text { Reliance } \\
(\%)\end{array}$ & 61 & 31 & 59 & 31 & 62 & 31 \\
\hline
\end{tabular}

As Table 4 indicates, decisions authored by the eight liberal Justices that rely on legislative history reach pro-employee dispositions $21 \%$ more

69. Percentages do not add up to 100 because the 322 majorities authored by liberal Justices include twenty-six cases with indeterminate ideological outcomes. See supra note 42 and accompanying text.

70. During the Burger era, liberal Justices' majorities favored employee positions by $56 \%$ to $35 \%$ (99 of 178 majorities were pro-employee; 62 of 178 were pro-employer). In the Rehnquist/Roberts years the ratio is $62 \%$ to $31 \%$, (90 of 146 majorities were pro-employee; 45 of 146 were pro-employer. The eight liberal Justices also rely on legislative history considerably more often than do their conservative counterparts. Of 322 majority opinions, just over $50 \%$ (162) relied on legislative history. By contrast, the eight conservative Justices have relied on legislative history in only $31 \%$ of their majority opinions ( 69 of 220). Of the remaining thirty-six decisions not authored by our two cohorts of Justices, twenty were per curiam opinions and the rest were authored by the five Justices serving for short periods during this thirty-seven year time frame-Justices Black (three), Harlan (four), Douglas (eight), Roberts (one), and Alito (zero). 
often than they reach pro-employer results. This liberal-conservative outcome differential rises by nearly one-third, to $30 \%$, when the decisions do not invoke legislative history. The tendency for liberal Justices' majorities to be "less liberal" when they rely on legislative history than when they do not is especially apparent during the Burger Court years.

The directional trend reported in Tables 3 and 4 is intriguing. We have posited the existence of a "magnifying effect" in liberal Justices' reliance on legislative history for liberal workplace statutes-that the eight Justices will become even more favorable toward employees than expected (based on their overall ideological voting record) when invoking this politicized resource. $^{71}$ Instead, we have observed in quantitative terms only a "supporting effect"; the liberal Justices rely on legislative history to reflect but not extend their pre-existing ideological preferences. Moreover, from a directional standpoint we have noted a modest "neutralizing effect"; the Justices' patterns of reliance point toward their being less ideological than expected when making use of legislative history. ${ }^{72}$

71. See supra text accompanying notes $4-5$.

72. We also ran a logistic regression analysis to examine whether legislative history reliance was significantly associated with either pro-employee or pro-employer results when controlling for the ideologies of the Justices and for certain other factors. Our dependent variable is a liberal or proemployee decision. We use the "old" conservatives (Justices Burger, Stewart, and Powell) as our baseline, so our reference to conservative Justices in this Table covers the five who served for extended periods of time after 1986. The regression includes 520 of the 534 decisions with an ideological direction that are addressed in our bivariate analyses. See Table 1 and supra note 42 . We omit the fourteen majorities with an ideological direction authored by short-term Justices Douglas, Black, Harlan, and Roberts. (The four short-term Justices authored sixteen majorities-see supra note 70-but two of these had indeterminate ideological results). Table $4 \mathrm{~A}$ reports our results.

Table 4A: Logistic Regression for Legislative History Use in Majority Opinions ( $\mathrm{N}=520)$

\begin{tabular}{|l|c|}
\hline Legislative History Majority & $.54(.47)$ \\
\hline Liberal Justices' Majority & $.78(.37)^{* *}$ \\
\hline Conservative Justices' Majority & $-.50(.40)$ \\
\hline Burger Court & $.04(.21)$ \\
\hline Liberals' Reliance on Legislative History & $-.43(.53)$ \\
\hline Conservatives' Reliance on Legislative History & $-.93(.66)$ \\
\hline Legislative History Dissent & $-1.14(.23)^{* *}$ \\
\hline Constant & $-.04(.36)$ \\
\hline $\begin{array}{l}* * \text { p\# .05; Prob > Chi-squared =000; Pseudo } \mathrm{R}_{2}=.09 \\
\text { Robust standard errors appear in parentheses next to coefficients }\end{array}$ \\
\hline
\end{tabular}

These results are consistent with our other findings. Liberal Justices are significantly more likely to reach liberal results when authoring majorities than are the older conservatives, while the newer conservatives are somewhat less likely to do so than their older conservative counterparts. Legislative history reliance in a majority opinion-by liberal or newer conservative Justices-is not associated with either liberal or conservative outcomes. The negative coefficient sign for liberal Justices' reliance on legislative history indicates there is a slight moderating effect, as reported in Tables 3 and 4 , and also Table 6 below. In addition, reliance on legislative history in dissent is significantly associated with a conservative result, indicating that the dissenters are using this history to support pro-employee or 
Before attempting to explain at a doctrinal level why the liberal Justices as a group use legislative history so regularly to support proemployer results, we examine the data for these eight Justices as individual authors of majority decisions. It is possible that for one or two Justices, legislative history reliance is powerfully associated with results that are less ideological than normal. Instances of significant neutralizing use could conceal many other liberal Justices' reliance on legislative history to promote their liberal policy preferences. In this regard, we also report findings on the majority opinions authored by our eight conservative Justices. The inclusion of all Justices with substantial tenure during this period enables us to place the liberal Justices' approach to legislative history in clearer perspective.

\section{Ideology and Reliance for Individual Justices}

In assessing the approaches to legislative history by individual Justices, we have built on our findings in Table 4. For each Justice, we present the percentage of majority opinions that rely on legislative history to help support pro-employee versus pro-employer results, followed by the percentage of majorities not using legislative history that arrive at these two outcomes. Our interest is in determining whether the outcome differential (between liberal and conservative results) when a Justice uses legislative history is more ideologically oriented than when that Justice refrains from doing so. For liberal Justices, evidence of more ideological uses would be that majority decisions using legislative history are more liberal than those not invoking that resource. For conservative Justices, evidence of ideologically-oriented reliance would be the opposite: that majority decisions using legislative history are less liberal than decisions not relying on it.

Table 5 refers to the difference between outcome differentials as our coefficient. The coefficient has a negative sign if a Justice's legislative history usage is associated with more neutral results, and a positive sign if the Justice's legislative history usage points toward results more consistent with her ideological orientation. Thus, for instance, Justice Brennan authored sixty-two majorities in our dataset (thirty-seven using legislative history and twenty-five not). His majority opinions relying on legislative history reached results that were $70 \%$ liberal and $16 \%$ conservative, a $54 \%$ differential. His majority opinions not relying on legislative history arrived at outcomes that were $76 \%$ liberal and $16 \%$ conservative, a $60 \%$ differential. For Justice Brennan, therefore, the coefficient is -6 : he was slightly less likely to follow his pro-employee voting preferences when writing majorities that invoked legislative history than when authoring

liberal outcomes. This finding comports with our discussion of when new conservatives use legislative history in their majorities. See infra Part III.B.3. 
majorities that did not. Table 5 also includes the total number of majority decisions by each Justice that rely on legislative history and the number that do not.

\section{Table 5: Ideological Direction of Legislative History (LH) Reliance by Individual Justices}

\begin{tabular}{|c|c|c|c|c|c|c|c|}
\hline & \multicolumn{3}{|c|}{ Legislative History Usage } & \multicolumn{3}{|c|}{$\begin{array}{c}\text { No Legislative History } \\
\text { Usage }\end{array}$} & \multirow[b]{2}{*}{ Coefficient } \\
\hline & $\begin{array}{c}\text { Liberal } \\
\text { Decisions } \\
(\%)\end{array}$ & $\begin{array}{c}\text { Conserv. } \\
\text { Decisions } \\
(\%)\end{array}$ & \begin{tabular}{|c|} 
Total \\
Decisions \\
Using LH
\end{tabular} & $\begin{array}{c}\text { Liberal } \\
\text { Decisions } \\
(\%)\end{array}$ & $\begin{array}{c}\text { Conserv. } \\
\text { Decisions } \\
(\%)\end{array}$ & $\begin{array}{c}\text { Total } \\
\text { Decisions } \\
\text { Not Using } \\
\text { LH }\end{array}$ & \\
\hline \multicolumn{8}{|l|}{ Liberals } \\
\hline Brennan & 70 & 16 & 37 & 76 & 16 & 25 & -6 \\
\hline Marshall & 66 & 25 & 32 & 74 & 16 & 19 & -17 \\
\hline Blackmun & 57 & 43 & 21 & 57 & 38 & 21 & -5 \\
\hline Stevens & 50 & 50 & 22 & 50 & 47 & 34 & -3 \\
\hline White & 28 & 59 & 29 & 47 & 33 & 30 & $-45 * *$ \\
\hline Souter & 50 & 50 & 10 & 85 & 15 & 13 & $-70^{* *}$ \\
\hline Ginsburg & 83 & 17 & 6 & 56 & 22 & 9 & +32 \\
\hline Breyer & 80 & 20 & 5 & 56 & 44 & 9 & +48 \\
\hline \multicolumn{8}{|c|}{ Conservatives } \\
\hline Burger & 60 & 30 & 10 & 100 & 0 & 3 & +70 \\
\hline Stewart & 47 & 41 & 17 & 40 & 50 & 10 & -16 \\
\hline Powell & 50 & 50 & 8 & 30 & 55 & 20 & -25 \\
\hline Rehnquist & 33 & 67 & 12 & 22 & 70 & 27 & -14 \\
\hline $\mathrm{O}^{\prime}$ Connor & 27 & 67 & 15 & 44 & 48 & 25 & $+36^{* *}$ \\
\hline Kennedy & 0 & 100 & 6 & 41 & 59 & 17 & $+82 * *$ \\
\hline Scalia & 0 & 100 & 1 & 28 & 64 & 25 & +64 \\
\hline Thomas & N/A & N/A & 0 & 33 & 67 & 24 & N/A \\
\hline
\end{tabular}

The table indicates that two of the eight liberals, Justices White and Souter, are significantly less ideological when relying on legislative history in their majority opinions than when not doing so. For four other liberal Justices, patterns of reliance point in the same moderating direction, although the results there are not significant. Only two of the eight, Justices Breyer and Ginsburg, are inclined to rely on legislative history to reach more liberal results than in their other majorities; however, this magnifying association is not significant.

Given the relatively low number of majority opinions authored by individual Justices, the significance findings for Justices Souter and White suggest the strength of their results. Moreover, these two liberal Justices 
are interesting because Justice Souter authors majorities that are somewhat more liberal than what is reflected in his overall vote score whereas Justice White's majorities are considerably more conservative than is his overall voting record. ${ }^{73}$ More generally, the six liberal Justices with negative coefficients include three Justices whose majority opinions lean heavily in a pro-employee direction and three others who have authored decisions more evenly divided in terms of outcome. ${ }^{74}$

On the other hand, Table 5 indicates that the two most recently appointed liberals, Justices Ginsburg and Breyer, have a more liberal record when they rely on legislative history than when they do not. In addition, two of the new conservatives, Justices O'Connor and Kennedy, are significantly more ideological when they invoke legislative history in their majority opinions--their results when relying on legislative history are distinctly more favorable to employers than when not doing so. This magnifying effect contrasts with the moderating association reported for two of the older conservatives, Justices Stewart and Powell, and also for Justice Rehnquist, who authored numerous majorities in each era. ${ }^{75}$

The differences between newer and older members of both the liberal and conservative cohort of Justices suggest that since 1986, the two groups may be using legislative history more often in support of their policy preferences than was true during the Burger era. Table 6 reports changes over time in the outcome-related reliance on legislative history by liberal and conservative Justices.

73. Justice Souter has supported employees' legal positions in $64 \%$ of nearly 200 cases overall, while favoring employees in $70 \%$ of the twenty-three majorities he has authored. Justice White supported employees' legal positions in $52 \%$ of more than 450 cases, but his fifty-nine majority opinions favored employees only $37 \%$ of the time. See supra note 46 for overall vote scores in our dataset. Justice White's unusually high proportion of pro-employer majority opinions reflects that he was often a swing vote, writing conservative majorities in close cases.

74. Justices Brennan (73\%), Marshall (69\%), and Souter (70\%) have authored majorities that favor employees roughly $70 \%$ of the time. By contrast, majorities written by Justices Blackmun (57\%), Stevens $(51 \%)$ and White $(37 \%)$ have a more balanced set of outcomes.

75. Chief Justice Burger, the third older conservative, is more ideological when using legislative history than when not doing so, but he authored only three majorities in our dataset that eschewed legislative history, making comparisons less reliable. Similarly, Justice Scalia has a very high positive coefficient, but he has written only one majority that relies on legislative history in our dataset. 
Table 6: Ideological Direction of Legislative History (LH) Reliance Over Time by Liberal and Conservative Justices

\begin{tabular}{|c|c|c|c|}
\hline & LH Used & No LH & \\
\hline & \multicolumn{2}{|c|}{ Liberal v. Conservative (\%) } & Coefficient \\
\hline \multicolumn{4}{|c|}{ Whole Period: 1969-2006 } \\
\hline Liberal Justices & 57 v. 36 & 61 v. 31 & $-9(322)$ \\
\hline $\begin{array}{l}\text { Conservative } \\
\text { Justices }\end{array}$ & 38 v. 57 & 34 v. 59 & $-6(220)$ \\
\hline \multicolumn{4}{|c|}{ Burger Court: 1969-1986 } \\
\hline Liberal Justices & 54 v. 38 & 59 v. 31 & $-12(177)$ \\
\hline $\begin{array}{l}\text { Conservative } \\
\text { Justices }\end{array}$ & 52 v. 40 & 36 v. 53 & $-29(95)^{* *}$ \\
\hline \multicolumn{4}{|c|}{ Rehnquist/Roberts Court: 1986-2006 } \\
\hline Liberal Justices & 62 v. 32 & 62 v. 31 & $-1(145)$ \\
\hline $\begin{array}{l}\text { Conservative } \\
\text { Justices }\end{array}$ & 15 v. 81 & 34 v. 62 & $+38(125)^{* *}$ \\
\hline
\end{tabular}

As Table 6 indicates, conservative Justices have become significantly more ideological in their use of legislative history during the Rehnquist/Roberts eras. Conservatives' reliance on this resource in the Burger years was associated with a moderating or pro-employee direction, but since 1986 their use of legislative history has shifted sharply in favor of employers. ${ }^{76}$ Liberal Justices' reliance on legislative history is associated with a somewhat more ideological orientation when moving from the Burger Court to the Rehnquist/Roberts years, although the change is not significant. Moreover, since 1986, liberals as a group have favored liberal over conservative results to the same extent whether relying on or eschewing use of legislative history.

76. For the difference between eras, $t=.0003$. The older conservatives (Justices Burger, Stewart, and Powell) had a coefficient of -25 during the Burger years, but the two other conservatives who served during the Burger period (Justices Rehnquist and O'Connor) had a coefficient of -21 , also indicating a moderating association. Justice Rehnquist is the one conservative to have authored a substantial number of majorities in both eras-26 before 1986 and 13 since that time. His coefficient was -23 in the Burger era and -15 in the Rehnquist/Roberts years. 
Still, two liberal Justices who authored a considerable number of majorities in both eras, Justices White and Stevens, used legislative history more often to support pro-employee results after 1986 than they had done before that time. ${ }^{77}$ Decisions authored by Justices White and Stevens, along with the record of Justices Ginsburg and Breyer, suggest that some liberal Justices may be inclined to invoke legislative history in the Rehnquist/Roberts years to advance their preferred policy outcomes, consistent with our initial hypothesis. We consider a strategic explanation for this approach by the liberal Justices in our discussion below.

IV.

\section{PRINCIPLED AND STRATEGIC USES OF LEGISLATIVE HISTORY}

Although our results may warrant further development or analysis in a number of directions, we focus here on two aspects of our findings. Each aspect relates directly to the central hypothesis underlying our empirical inquiry - that liberal Justices may use legislative history on a systemic basis to advance their ideological agenda.

First, Tables 3, 4, and 5 indicate that for six of the eight liberal Justices, legislative history reliance is associated with a moderating set of ideological results. The association is significant for two of the liberals (Justices White and Souter), and directional for four others (Justices Brennan, Marshall, Blackmun, and Stevens) and for the liberal Justices as a group. These results are important because they call into question our assumption about legislative history as an ideologically-charged resource. In Part IIIA, we contend that there are principled, doctrinal reasons why liberal Justices so regularly rely on the legislative history accompanying liberal pro-employee statutes to support conservative, pro-employer outcomes.

Second, Tables 5 and 6 suggest that legislative history usage has taken on a more politicized complexion in the years since 1986, for Justices in both the liberal and conservative camps. We examine the possibility that this shift reflects the development of a Scalia Effect, based on Justice Scalia's high-profile stance opposing legislative history reliance. By initially and persistently expressing his unqualified hostility to the use of legislative history, Justice Scalia has put his colleagues on notice that they should invoke this resource at their peril. Other Justices must therefore weigh whether to rely on legislative history with the knowledge that if they do so, they risk losing his support for their reasoning. In Part IIIB, we

77. Justice White authored forty-two majorities in the Burger years and seventeen during the Rehnquist period. His coefficient changed from -89 to +62 between the two eras. Justice Stevens wrote twenty-five majorities for the Burger Court and has authored thirty-one majority opinions since 1986. His coefficient changed less dramatically, from -8 to +1 , but it too shifted toward more frequent reliance on legislative history to favor employees. 
explore how this strategic aspect of judicial reasoning has contributed to an altered ideological pattern of legislative history usage for liberal Justices and perhaps for conservatives as well.

\section{A. Liberal Justices and Principled Reliance on Legislative History}

We observed early on that legislative history accompanying employee protection laws is likely to include a considerable array of statements that explain, justify, or elaborate upon a fundamentally pro-employee set of legislative preferences. ${ }^{78}$ At the same time, the fact that these workplace statutes favor the legal interests of employees does not mean the enacted provisions or their accompanying legislative records are monolithic. Major federal workplace legislation is invariably a product of negotiation and deal-making among multiple participants over an extended period of time. The chief sponsors and bill managers for comprehensive regulatory schemes such as the NLRA, ERISA, and antidiscrimination laws ${ }^{79}$ cannot hope to navigate the politically sensitive internal procedures in each chamber without brokering or acceding to some tradeoffs among competing interests.

Congressional negotiation is reflected in the work product of authorizing committees and in the floor debates in both houses. Members understand they are voting on a bill that accords new rights and protections for employees as its major premise. They also recognize, however, that those rights and protections are reconciled with the interests of private employers in maintaining a certain level of efficient and profitable operation, and with the interests of public employers in avoiding undue burdens on the fulfillment of government's obligations to its citizens and taxpayers.

Congress regularly seeks to accommodate such major and minor legislative objectives in furtherance of its policy-making agenda. With respect to employee protection statutes, the accommodation takes two basic forms. One is the insertion in text of an employer defense or exemption that immunizes business or government from liability in certain settings. ${ }^{80}$ The other is compromise on a particular issue or provision that reflects give

78. See supra text accompanying notes 2-3, 20-21

79. See National Labor Relations Act (NLRA), 29 U.S.C. $\S 151$ et seq. (2000); Employee Retirement Income Security Act (ERISA), 29 U.S.C. $\S 1001$ et seq. (2000); Age Discrimination in Employment Act (ADEA), 29 U.S.C. $\S 621$ et seq. (2000); Title VIl of the Civil Rights Act of 1964, 42 U.S.C. $\$ 2000 \mathrm{e}$ et seq. (2000).

80. See, e.g., Title VII of the Civil Rights Act of 1964, 42 U.S.C. $\S 2000 \mathrm{e}-2(\mathrm{~h})$ (protecting bona fide seniority systems); Age Discrimination in Employment Act, 29 U.S.C. $§ 623(\mathrm{f}$ ) (protecting bona fide occupational qualifications based on age, and exempting decisions based on reasonable factors other than age); National Labor Relations Act, 29 U.S.C. $\S 152(3),(11)$ (exempting supervisors and independent contractors from the Act's coverage). 
and take between supporters of employee and employer interests during the legislative process. ${ }^{81}$

These two forms of textual adjustment are frequently accompanied by explanatory statements from the committees or the individual members responsible for negotiating them. Thus, there is legislative history that justifies or elaborates on the meaning of employer defenses or exemptions included in the text. There also is legislative history that chronicles or explains the existence of a compromise between bill supporters and critics on the issue in question. In addition, the legislative record that attends enactment of an employee protection bill may suggest in a third, more oblique, way that a particular issue was resolved in favor of employer interests. We refer here to legislative history indicating that the right, protection, or remedy asserted on behalf of employees was not embraced or perhaps even referenced in committee reports and key floor statements promoting the language in question, and therefore that employees and their supporters may have overreached in their claims.

All three of these doctrinal categories may be thought of as proemployer legislative history within a pro-employee statute, and all three are invoked with some regularity by liberal Justices to help explain or justify pro-employer results. Indeed, of nearly sixty pro-employer majorities relying on legislative history authored by the liberal Justices, some threefifths fall into one or more of the categories identified above. To illustrate these patterns of reliance, we briefly discuss several Court decisions from each category.

\section{Employer Defenses or Immunities}

One important example of an employer defense is section 703(h) in Title VII of the 1964 Civil Rights Act, ${ }^{82}$ which protects employers when they apply different terms or conditions of employment pursuant to a bona fide seniority system. In American Tobacco Co. v. Patterson, ${ }^{83}$ Justice White, writing for the majority, concluded that Congress intended to exempt post-Act as well as pre-Act seniority systems, ${ }^{84}$ even though protecting post-Act systems would likely extend the effects of pre-Act discrimination against racial minorities. Justice White noted that section

81. See, e.g., 1991 Civil Rights Act, 42 U.S.C. $\S \S 1981$ a(a)-(b) (providing compensatory and punitive damages for intentional discrimination but imposing limitations as to dollar amounts); Doe $\mathrm{v}$. Chao, 540 U.S. 614, 620-22 (2004) (describing the compromise on $\S 2(\mathrm{~g})$ (4) of the Privacy Act (5 U.S.C. $\S 552 \mathrm{a}(\mathrm{g})(4))$ that guarantees a $\$ 1000$ damages award only to plaintiffs who suffered some actual damages); Mass. Mutual Life v. Russell, 473 U.S. 134, 139-46 (1985) (describing the compromise on $\S$ 409 of ERISA ( 29 U.S.C. $\$ 1109$ ) that allows a benefit plan but not a plan fiduciary to be held liable for the improper processing of benefits claims). See generally MARTIN SHAPIRO, LAW AND POLITICS IN THE SUPREME COURT 110 (1964).

82. 42 U.S.C. $\$ 2000 \mathrm{e}-2(\mathrm{~h})$.

83. 456 U.S. 63 (1982).

84. Id. at 77 . 
703(h) did not distinguish on its face between pre- and post-Act seniority systems. ${ }^{85}$ He then reviewed in depth the drafting history of section 703(h), relying on several Senate floor exchanges among key participants to confirm that Congress meant for all bona fide seniority rights to be unaffected by the bill, even if this left black employees worse off than their more senior white counterparts. ${ }^{86}$

A decade earlier, Justice Brennan relied on legislative history to help support the applicability of an employer defense under the NLRA. In Beasley v. Food Fair of North Carolina, ${ }^{87}$ the Court held that NLRA provisions added in 1947 excluding supervisors from the Act's protections (thereby allowing employers to discharge supervisors on account of their membership in a union) also freed employers from liability under state laws that prohibited termination based on union membership. ${ }^{88}$ Although the NLRA text was not entirely clear, Justice Brennan for the majority relied primarily on House and Senate committee reports to conclude that Congress's dominant purpose in adding the new language was to avoid problems of divided loyalty by insulating employers from all efforts by state or federal agencies to make them treat their supervisors as employees. ${ }^{89}$

More recently, in Albertson's Inc. v. Kirkingburg, ${ }^{90}$ Justice Souter invoked legislative history to help explain why an employer could use noncompliance with federal safety regulations to justify its determination that a visually impaired truck driver was not a "qualified" individual with a disability under the Americans with Disabilities Act. The decision also involved other interpretive issues under the $\mathrm{ADA},{ }^{91}$ but on the question of the employee's being "qualified," Justice Souter relied on Senate and House committee reports to establish Congress's understanding that federal safety rules would limit application of the ADA to individuals able to meet the relevant physical qualification standards. ${ }^{92}$

These three cases are representative of many others in which liberal Justices invoke legislative history to help sustain the applicability of an employer exemption or defense. The history is used in some majority

85. Id. at 69 .

86. Id. at 72-75. See also Firefighters Local Union 1784 v. Stotts, 467 U.S. 561, 580-82 (1984) (White, J.) (relying on the legislative history of section $706(\mathrm{~g})$ of Title VII in limiting lower courts' authority to award make-whole relief that is inconsistent with the terms of a bona fide seniority system).

87. 416 U.S. 653 (1974).

88. Id. at 662 .

89. Id. at 659-62.

90. 527 U.S. 555 (1999).

91. See id. at 562-67 (holding the lower court erred in determining that the employee's monocular vision impairment made him per se disabled under ADA standards).

92. Id. at 570-74. 
opinions to clarify the meaning of ambiguous text $\mathrm{t}^{93}$ and in other instances to confirm that the text means what it seems to say. ${ }^{94}$ The Justices interpret the meaning of employer defenses or exemptions under ERISA ${ }^{95}$ and some minor workplace-related statutes ${ }^{96}$ as well as the NLRA $^{97}$ and federal antidiscrimination laws. ${ }^{98}$

\section{Compromises Involving Competing Approaches}

The liberal Justices have repeatedly invoked legislative history to support pro-employer outcomes by demonstrating how this history reveals or confirms the existence of a negotiated arrangement among interested groups or legislators on a particular issue. In Mohasco Corp. v. Silver, ${ }^{99}$ Justice Stevens for the majority addressed the time requirements for filing Title VII charges. The Court reviewed at length the drafting history from both the 1964 Act and its 1972 amendments, concluding that a charge must be filed at the EEOC within 300 days even in states where the charge is initially brought to a state agency for consideration. ${ }^{100}$ In noting the development of a compromise that set 300 days as a firm limit, Justice Stevens referred to members' competing interests of preserving remedial options for victims of discrimination, respecting the role of state agencies in resolving charges, and minimizing the burdens of having to defend stale or dormant claims. ${ }^{101}$

Fourteen years later, the Court in Landgraf v. USI Film Products ${ }^{102}$ relied on legislative history to establish that two pivotal groups of bill supporters had in effect agreed to disagree on whether certain controversial 1991 amendments to Title VII should be applied retroactively. Justice Stevens for the majority conducted a careful review of earlier bill versions and Senate floor debates, and concluded there was a broad understanding that no deal could be reached on the contentious issue of retroactivity but that neither side wanted this lack of agreement to derail the bill's passage. ${ }^{103}$ The majority opinion went on to hold in favor of the traditional

93. See, e.g., N.L.R.B. v. Enter. Ass'n of Steam \& Gen. Pipefitters, 429 U.S. 507, 517-18, 526 (1977) (White, J.); Vance v. Bradley, 440 U.S. 93, 98-105 (1979) (White, J.).

94. See, e.g., N.L.R.B. v. Local 103, 434 U.S. 335, $347-49$ (1978) (White, J.); Alessi v. Raybestos-Manhattan, Inc., 451 U.S. 504, $515-21$ (1981) (Marshall, J.); Shaw v. Delta Airlines, 463 U.S. 85, 98-100 (1983) (Blackmun, J.).

95. See Shaw, 463 U.S. at 98-100; Alessi, 451 U.S. at 515-21 .

96. See Vance, 440 U.S. at 98-105.

97. See Local 103, 434 U.S. at 348-49; Enter. Ass'n., 429 U.S. at 517-18, 526.

98. See Firefighters v. Stotts, 467 U.S. 561, 580-82 (1984) (White, J.).

99. 447 U.S. 807 (1980).

100. Id. at $818-24$.

101. Id. at $820-23$.

102. 511 U.S. $244,244-45$ (1994).

103. Id. at $250-63$. 
presumption against retroactivity, noting the absence of a congressional intent to overcome that presumption. ${ }^{104}$

In addition to finding legislative record evidence of Title VII bargains that favored employer legal positions, the liberal Justices have relied on such evidence with respect to a series of more minor workplace law statutes. In Jackson Transit Authority v. Amalgamated Transit Union, ${ }^{105}$ Justice Blackmun for the majority addressed the meaning of section 13(c) in the Urban Mass Transportation Act of $1964,{ }^{106}$ which required states and localities to preserve collective bargaining rights when using federal funds to help purchase a privately owned transit company. The issue was whether section 13(c) permitted the union to sue in federal court for alleged violations; the majority concluded that while the text was ambiguous, the legislative history definitively resolved the matter against such a federal right of action. ${ }^{107}$ Justice Blackmun reviewed committee reports and floor debates at length, determining that section 13(c) was meant to promote a balanced regulatory scheme, accommodating state law to collective bargaining rights but not supplanting state labor law processes with a federal law of collective bargaining. ${ }^{108}$

More recently, Justice Souter in Doe v. Chao ${ }^{109}$ relied on legislative history accompanying the Privacy Act of $1974^{110}$ to confirm that the statute's award of $\$ 1000$ in presumed damages to individuals adversely affected by a federal agency violation did not apply unless a victim suffered some actual damages. The majority pointed to an uncodified section of the Act that seemed to defer the question of presumed damages by assigning the matter to a newly established Privacy Protection Study Commission. ${ }^{111}$ But Justice Souter also invoked the Act's drafting history to underscore the Court's holding; he emphasized that the Senate bill's provision authorizing presumed damages had been deleted in the final version. ${ }^{112}$

Once again, these cases are illustrative of many more in which liberal Justices find persuasive evidence of a congressional deal in the legislative record, evidence that helps resolve a controversy in favor of the employer's legal position. The decisions arise under comprehensive workplace

104. Id. at 256, 280, 286. See also Rivers v. Roadway Express Inc., 511 U.S. 298, 304-09 (1994) (Stevens, J.,) (concluding that the traditional presumption against retroactivity was not disturbed where the legislative history of the 1991 Civil Rights Act revealed an agreement to disagree over whether to give retroactive effect to the override of a particular Supreme Court decision).

105. 457 U.S. 15 (1982).

106. Pub. L. No. 88-365, $\S 10($ c), 78 Stat. 307 (1964), as amended by Pub L. No 89-562, $\S 2$ (b)(1), 80 Stat. 716 (1966).

107. Id. at $23-24$.

108. Id. at 24-29.

109. Chao, 540 U.S. 614 (2004).

110. See 5 U.S.C. $\$ 552$ a (2000).

111. Id. at 622 .

112. Id. at 622-23. 
regulation schemes besides Title VII, such as ERISA, ${ }^{113}$ OSHA, ${ }^{114}$ and the NLRA. ${ }^{115}$ Apart from the laws addressed in Jackson Transit and Doe $v$. Chao, legislative history identifying compromises has been used to support the employer's legal position in several other similarly narrow statutes. ${ }^{116}$

\section{Overreaching by Employees}

Finally, liberal Justices have frequently relied on legislative history to show that Congress simply did not go as far as employees and their advocates contend it did. Such uses of the legislative record differ from invoking committee commentary or drafting history to disclose or confirm the existence of a negotiated compromise; Justices reference legislative history here in a way more akin to the maxim of the dog that didn't bark. ${ }^{117}$ The Court in this third group of decisions relies on legislative history to demonstrate or reinforce the implausibility of Congress having extended a right, remedy, or procedure as sought by employees, because Congress never endorsed or in some instances even contemplated such an extension when considering the matter in its deliberative process.

In Allied Chemical Workers Local 1 v. Pittsburgh Plate Glass Co., ${ }^{118}$ Justice Brennan for the majority addressed whether the NLRA required an employer to bargain with its union over benefits levels for retirees. Rejecting the agency's interpretation that retirees' benefits were a mandatory subject of bargaining, the Court held that mandatory bargaining covered only the terms and conditions of employment for current employees. ${ }^{119}$ Justice Brennan relied heavily on committee reports to show how Congress intended that the term "employee" not be stretched beyond its ordinary meaning-individuals working for another for wages or

113. See Mass. Mutual Life Ins. Co. v. Russell, 473 U.S. 134, 145-46 (1985) (Stevens, J.).

114. See Indus. Union Dept., AFL-ClO v. Am. Petroleum Inst., 448 U.S. 607, 646-49 (1980) (Stevens, J.).

115. See N.L.R.B. v. United Food \& Commercial Workers Local 23, 484 U.S. 112, 124-26 (1987) (Brennan, J.). See also Firefighters v. Stotts, 467 U.S. 561 at 580-82 (White, J.) (discussing assurances on limits of the Court's remedial powers that Title VII sponsors and managers continually gave bill's critics and undecided members during floor debates).

116. See Karahalios v. Nat'l Fed'n of Fed. Employees Local 1263, 489 U.S. 527, 533-34 (1989) (White, J.) (construing text of the 1978 Civil Service Reform Act); United Bhd. of Carpenters Local 610 v. Scott, 463 U.S. 825, 834-37 (1983) (White, J.) (construing language of 42 U.S.C. $\$ 1985(3)$ ); U.S. Civil Serv. Comm'n v. Nat'l Ass'n of Letter Carriers, 413 U.S. 548, 570-71 (1973) (White, J.) (construing language of the Hatch Act).

117. See A. Conan Doyle, Silver Blaze, in The Complete Sherlock Holmes 383, 400 (1938). See generally City of Rancho Palos Verdes v. Abrams, 544 U.S. 113, 132 (2005) (Stevens, J., concurring) (applying the "dog that didn't bark" maxim); Koons Buick Pontiac GMC, Inc. v. Nigh, 543 U.S. 50, 63 (2004) (Ginsburg, J.) (same); United States v. Am. Library Ass'n, 539 U.S. 194, 239-41 (2003) (Souter, J., dissenting) (same).

118. 404 U.S. 157 (1971).

119. Id. at $165-66$. 
salaries, not those who, due to retirement or any other reason, have ceased to do so. ${ }^{120}$

A decade later, the Court in Kremer v. Chemical Construction Co. ${ }^{121}$ invoked legislative history when holding that Title VII did not repeal other provisions of federal law and thus did not deny res judicata or collateral estoppel effect to a state court judgment affirming that an employment discrimination claim was unproved. Justice White for the majority reviewed at length the committee report commentary and floor debate accompanying the 1964 Act and 1972 amendments. ${ }^{122}$ He concluded that while members expressed concerns that the adequacy of state employment discrimination remedies might be too readily assumed, they never envisioned an absolute right to relitigate issues resolved by state courts. ${ }^{123}$

In Mead Corp. v. Tilley, ${ }^{124}$ the Court confronted the question of whether an ERISA section providing for the orderly distribution of defined benefit plan assets upon termination also created a right for plan participants to recover anticipated benefits not otherwise protected. Justice Marshall for the majority focused on the conference committee deliberations, because the allocation provision at issue had been cobbled together in conference by combining features of the House and Senate bills. $^{125} \mathrm{He}$ concluded that nothing in the conference report and its statement of managers suggested or implied that the committee intended to make this section a source of benefit entitlements rather than simply a scheme for the distribution of plan assets. ${ }^{126}$

More recently, in United States $v$. Burke, ${ }^{127}$ the Court had to decide whether backpay awards under Title VII were excludable from gross income under the Internal Revenue Code. Justice Blackmun for the majority first determined that the relevant revenue code provision excluded only income for tort-like damages received on account of personal injuries; ${ }^{128}$ he then concluded that Title VII's pre-1991 focus on restorative back pay awards did not qualify within the meaning of the tax code exclusion. ${ }^{129}$ In reaching this conclusion, Justice Blackmun invoked legislative history from the 1972 amendments characterizing the remedial scheme as no more than restorative, and also relied on committee reports

120. Id. at $166-68$.

121. 456 U.S. $461(1982)$

122. Id. at $470-76$.

123. Id. at 473-76. See also Kaiser Steel Corp. v. Mullins, 455 U.S. 72, $86-88$ (1982) (White, J.) (relying on legislative history to support holding that 1980 ERISA amendments do not repeal by implication earlier-enacted defenses claimed by the employer).

124. 490 U.S. 714 (1989).

125. Id. at 723-24.

126. Id.

127. 504 U.S. 229 (1992).

128. Id. at 233-37.

129. Id. at 241 . 
accompanying the 1991 amendments, which described the newly added monetary damages remedies as taking the statute beyond its old equitable relief limitations. ${ }^{130}$

As was true for our two prior categories, there are many more decisions in which liberal Justices rely on legislative history to help explain why the right or remedy sought by employees would exceed what Congress meant to provide for in its legislative approach. Although the examples presented in text arose under three major workplace protection statutesNLRA, ERISA, and Title VII ${ }^{131}$-there are numerous instances in which liberal Justices have relied on the legislative history of more minor statutes to help rebut such overly ambitious claims by employees and their advocates. ${ }^{132}$ In this regard, legislative record evidence is most often used to confirm or reinforce the Court's conclusion that the text does not cover what employees' counsel wants it to, but occasionally the majority has invoked legislative history to help establish such limits in the face of ambiguous text. ${ }^{133}$

\section{Alternate Explanations Considered}

The doctrinal categories we have identified are present in most decisions where liberal Justices invoke the legislative record to support results favorable to employers. There are a number of pro-employer decisions in which the use of legislative history does not fall into any of these categories. ${ }^{134}$ Nonetheless, our three doctrinal approaches offer a principled, law-based explanation for why legislative history accompanying liberal statutes is regularly relied on by liberal Justices to help justify conservative outcomes.

130. Id. at $239,241$.

131. See also United Mine Workers of Am. v. Robinson, 455 U.S. 562, 570-72 (1982) (Stevens, J.) (construing legislative history of the NLRA); Kaiser Steel Corp. v. Mullins, 455 U.S. 72, 86-88 (1982) (White, J.) (construing legislative history of ERISA); Laborers Health and Welfare Trust Fund v. Advanced Lightweight Concrete Co., 484 U.S. 539, 546-49 (1988) (Stevens, J.) (construing legislative history of ERISA); Pegram v. Herdrich, 530 U.S. 211 , 229-30 (2000) (Souter, J.) (construing legislative history of ERISA); Espinoza v. Farah Mfg. Co., 414 U.S. 86, 88-90 (1974) (Marshall, J.) (construing legislative history of Title VII).

132. See, e.g., Universities Research Ass'n Inc. v. Coutu, 450 U.S. 754, 773-77 (1981) (Blackmun, J.) (construing legislative history of the Davis-Bacon Act); BATF v. Fed. Labor Relations Auth., 464 U.S. 89, 99-105 (1983) (Brennan, J.) (construing legislative history of the Civil Service Reform Act of 1978); Herb's Welding, Inc. v. Gray, 470 U.S. 414, 420-24 (1985) (White, J.) (construing legislative history of the Longshoreman's and Harbor Workers' Compensation Act); Webb v. Bd. of Educ. of Dyer County., Tenn., 471 U.S. 234, 241 \& n.16 (1985) (Stevens, J.) (construing legislative history of the Civil Rights Attorney's Fees Awards Act of 1976); Breuer v. Jim's Concrete of Brevard, lnc., 538 U.S. 691, 695 , n.l (2003) (Souter, J.) (construing legislative history of a FLSA provision creating a right to "maintain" civil action).

133. See, e.g., Herb's Welding Inc., 470 U.S. at 421-23; BATF, 464 U.S. at 103-04.

134. See, e.g., United States v. Cleveland Indians Baseball Co., 532 U.S. 200, 214-15 (2001) (Ginsburg, J.); Pauley v. BethEnergy Mines, 501 U.S. 680, 697-99, 705 (1991) (Blackmun, J.); Fed. Mar. Comm'n v. Pacific Mar. Ass'n, 435 U.S. 40, 54 (1978) (White, J.). 
It is possible that non-doctrinal factors may also be contributing to our findings. One potential factor involves the power of assigning majority opinions. Liberal Justices may follow divergent ideological patterns of legislative history reliance depending on whether they are assigned to draft a majority opinion by the usually conservative-voting Chief Justice (Justices Burger or Rehnquist during this period) or by the most senior associate Justice, who would be a fellow liberal during these years. ${ }^{135}$ The assumption here would be that if the Chief Justice has voted with them (and hence presumably assigns them the opinion), the liberal Justices' reliance on legislative history should be linked to pro-employer results substantially more often than pro-employee outcomes. Conversely, if the Chief has not voted with them (and hence they are presumably self-assigning), the liberal Justices' use of legislative history should much more likely be associated with pro-employee rather than pro-employer results.

Were ideological patterns of legislative history usage to vary based on whether the Chief Justice exercised the power of assignment, this variation might well conceal the genuine strength of policy preferences in explaining the liberals' regular use of legislative history to support conservative outcomes. In fact, however, we found no such variation. Liberal Justices do rely on legislative history more heavily in self-assigned majorities when compared with majorities assigned by the Chief Justice. ${ }^{136}$ But liberals use legislative history to help support pro-employer outcomes slightly more often than they do to help explain pro-employee results whether the majorities are assigned by the Chief or by fellow liberal Justices. ${ }^{137}$ Further, because the Chief Justice is on their side in four-fifths of the majority opinions authored by the liberal Justices, it is especially noteworthy that legislative history is used in these majorities to support proemployer results and pro-employee outcomes at similarly substantial levels. ${ }^{138}$ Given these findings, there is no reason to believe that our doctrinal account of liberal Justices invoking legislative history to help

135. From 1969 to 2006 , the senior associate Justice assigning majority opinions when the Chief was on the other side would almost invariably have been Justice Brennan (1969 to 1990); Justices White, Marshall, or Blackmun (1990 to 1994); or Justice Stevens (1994 to 2006).

136. When the Chief Justice joins them in the majority, liberal Justices rely on legislative history $47 \%$ of the time ( 121 of 257 decisions). When the Chief Justice is not in the majority, liberal Justices rely on legislative history $63 \%$ of the time (forty-one of sixty-five decisions).

137. Liberal Justices use legislative history in $53 \%$ of the 103 pro-employer majority opinions joined by the Chief Justice and in $43 \%$ of the 133 pro-employee majorities that the Chief Justice joins. When the Chief Justice is not in their majority, liberals rely on legislative history in $75 \%$ of their four pro-employer majorities and in $63 \%$ of their fifty-six pro-employee majorities. Details of these and all other calculations are on file with the authors.

138. See supra note 137. The difference between legislative history usage in pro-employer and pro-employee decisions when the Chief Justice assigns is not close to significant $(t=.38)$. The Chief Justice's assignment control for $80 \%$ of all majority opinions in our dataset (257 of 322) is consistent with findings reported in other Supreme Court studies. See EPSTEIN \& KNIGHT, supra note 22, at 128 and sources cited therein. 
justify conservative results is shaped or even substantially influenced by control over the assignment power.

Apart from the institutional factor of who assigns majority opinions, liberal Justices may act from more directly instrumental motives. One possibility is that the liberals adapt their reasoning approach based on their appreciation for how legislative history from pro-employee workplace protection statutes can help them to support preferred policy outcomes in important cases. The contention is that liberal Justices may seek to enhance their "major" policy preference by promoting as a "minor" methods preference that legislative history reliance is principled and impartialoften leading toward results contrary to their ideological interests. ${ }^{139}$ The methods preference is deemed to be minor because the pro-employer decisions it helps justify rarely carry substantial policy implications. Judge Richard Posner has suggested that the Justices sometimes engage in this sort of strategic behavior at a subconscious level with regard to constitutional matters, voting against their personal values or preferences in cases with relatively minor policy consequences so that they may appear "principled" on their larger approach to an area of constitutional doctrine or a method of constitutional interpretation. ${ }^{140}$

It is difficult to accept the persuasiveness of this contention in the instant setting for two reasons. First, if the liberal Justices regularly operated in such an instrumental fashion-even if mostly at a semiconscious level-one would expect to find some evidence of strategic ruminations in the personal notes or memos they compiled during decades of service on the Court. To our knowledge, scholarly examination of the Brennan, Marshall, Powell, and Blackmun papers has not produced such evidence. More importantly, there is little reason to believe that the Justices anticipated-or could have anticipated on a systemic basis-which workplace law decisions were likely to have substantial policy consequences and which were not. Liberal Justices have certainly invoked legislative history to help justify major pro-employee decisions under leading regulatory schemes such as Title VII ${ }^{141}$ and the NLRA. ${ }^{142}$ But

139. Cf. Richard A. Posner, The Supreme Court, 2004 Term; Foreword: A Political Court, 119 HARV. L. REV. 31, 51-52 (2004) (discussing how Justices in Supreme Court cases may declare they are voting against their policy interests to enhance their images as principled decision-makers constrained by precedents or other legal norms).

140. See id., at 50-51 (suggesting that Justice Scalia's vote to protect flag burning under the First Amendment had a very limited impact in policy terms but in effect helped promote his textualist approach to constitutional analysis, an approach that could, if adopted by a majority, make an overruling of Roe $v$. Wade more likely.

141. See, e.g., United Steelworkers of Am. v. Weber, 443 U.S. 193, 202-08 (1979) (Brennan, J.) (using legislative history to help justify lawfulness of voluntary affirmative action); Burlington N. \& Santa Fe Ry. Co. v. White, 126 S.Ct. 2405, 2417 (2006) (Breyer, J.) (using legislative history to help support broad coverage under an anti-retaliation provision of the statute).

142. See, e.g., Complete Auto Transit, Inc. v. Reis, 451 U.S. 401, 408-15 (1981) (Brennan, J.) (using legislative history to help justify the preclusion of damages actions against individual employees 
liberals also have relied on legislative history to help support pro-employer results of considerable consequence under those two comprehensive statutes ${ }^{143}$ and various others. ${ }^{144}$

A related but more complex account of strategic motivation offered by political scientists Lee Epstein and Jack Knight suggests that legislative history is one of several legal factors operating as a constraint on Justices' policy preferences, one they may feel obligated to follow even when it leads to outcomes they would not ordinarily prefer. ${ }^{145}$ On this theory, the original intent of statutory drafters, like the principle of stare decisis, is a presumptively impartial doctrine that encourages liberal Justices to modify their policy preferences so as to keep faith with various audiences, especially the public and the legal community, which expect them to reach decisions based on legitimate rule-of-law norms. ${ }^{146}$ Epstein and Knight do not regard fidelity to these norms as a driving or primary goal of the Justices, but rather as operating to provide a necessary framework for their choices and at least occasionally to shape the outcomes they reach. ${ }^{147}$

We find Epstein and Knight's account both more appealing and also more consistent with the doctrinal explanations we have offered. Statutory cases heard by the Court can often be decided in either direction on plausible legal grounds, and the Justices have before them many reasoned arguments derived from a range of interpretive resources other than legislative record evidence. Assuming that individual values and policy preferences do influence the weight or priority given to these resources, the often subconscious nature of such values and preferences makes it difficult to discover whether invocation of legislative history in a majority opinion actually helped motivate a result or simply helped explain it. ${ }^{148}$

for a wildcat strike); N.L.R.B. v. Town \& Country Elec., 516 U.S. 85, 91 (1995) (Breyer, J.) (using legislative history to help justify "salting" as a lawful union organizing technique under the Act).

143. See, e.g., Landgraf v. USI Film Prods., 511 U.S. 244, 262-63 (1994) (Title VII); Firefighters Local Union 1784 v. Stotts, 467 U.S. 561, 579-82 (1984) (Title VII); Espinoza v. Farah Mfg. Co., 414 U.S. 86, 88-90 (1973) (Title VII); Linden Lumber Div. v. N.L.R.B., 419 U.S. 301, 307-08 (1974) (NLRA); Allied Chem. \& Alkali Workers Local Union No. 1 v. Pittsburgh Plate Glass Co., 404 U.S. 157, 165-71, 185-88 (1971) (NLRA).

144. See, e.g., Pegram v. Herdrich, 530 U.S. 211, 232 (2000) (ERISA); Mass Mutual Life Ins. Co. v. Russell, 473 U.S. 134, 140-141, 145-48 (1985) (ERISA); United Bhd. of Carpenters \& Joiners Local 610 v. Scott, 463 U.S. 825, 834-38 (1983) (\$ 1985(3)); U.S. Civil Serv. Comm'n v. Nat'l Ass'n of Letter Carriers, 413 U.S. 548, 559-60, 563-67, 570-74 (1973) (Hatch Act); Boys Mkts., Inc. v. Retail Clerks Union Local 770, 398 U.S. 235, 245-46 (1970) (Norris-LaGuardia Act).

145. See EPSTEIN \& KNIGHT, supra note 22, at 40-45.

146. See id. at $40,45,157-59,163-64$

147. See id. at $45,165-67,172,177$ (discussing evidence that the doctrine of stare decisis structures and influences the Court's decisions). For an insightful recent discussion of how judges' legal training and individual professional experiences may strengthen their interest in adhering to doctrinal or principled justifications, see LAWRENCE BAUM, JudGES AND THEIR AUDIENCES: A PERSPECTIVE ON JUDICIAL BEHAVIOR 88-117 (2006)

148. See generally Dennis J. Hutchinson, THE MAN Who ONCE WAS Whizzer White 349-50, 445-47 (1998); John M. Ferren, General Yamashita and Justice Rutledge, 28 J. SUP. CT. HIST. 54, 70-73 (2003). 
At the same time, we can not overlook the volume and proportion of workplace law decisions in which liberal Justices rely on legislative history as an aid in justifying their departure from presumed ${ }^{149}$ policy preferences. The extent to which reliance is associated with pro-employer outcomes invites an explanation that goes beyond viewing legislative history as a merely instrumental or episodic constraint. In this regard, it is worth noting that before 1986, conservative Justices also regularly relied on legislative history to help justify results contrary to their preferred policy outcomes. ${ }^{150}$ Further, the three doctrinal categories implemented by liberal Justices in workplace law have been invoked by some of these same liberals to support "conservative" results when applying other federal statutes. ${ }^{151}$ In short, the liberal Justices' recurring reliance on legislative history as an impartial interpretive asset may reflect a commitment that is pervasive and principled rather than occasional and opportunistic.

\section{Interpretive Philosophy}

Based on our earlier findings, the liberal Justices are significantly more likely than their conservative counterparts to rely on legislative history. ${ }^{152}$ The liberals' favorable stance toward this history is distinctive in both the

149. Our reference to "presumed" preferences is meant to acknowledge that liberal Justicesespecially those with voting records closer to a 50:50 split (see supra note 46)-will not automatically favor a pro-employee outcome in a particular case. A liberal Justice's reliance on legislative history in a decision that reaches a pro-employer result may at times reflect that the Justice's policy preference accords with the legislative record evidence being invoked, rather than that the legislative record is itself serving to constrain that preference. Nonetheless, given the voting patterns of these eight liberal Justices-six of whom favor the legal positions of employees and unions over three-fifths of the time under both the Spaeth issue codes and our dataset-it is appropriate to assume that the liberals are regularly using legislative history to help explain majority opinions that are inconsistent with the authors' preferred policy outcomes.

150. See supra Table 6; supra notes 74-75 and accompanying text. Although the conservatives were relying on legislative history that was consistent with the overall pro-employee thrust of the statutes, their tendency to reach more liberal opinions when using this resource than when not doing so supports our broader notion that many Justices view legislative history as a principled interpretive asset, justifying their constrained policy choices on more than an anecdotal basis.

151. See, e.g., Chem. Mfrs. Ass'n. v. NRDC, 470 U.S. 116, 125-29 (1985) (White, J.) (relying on evidence of a congressional compromise in holding that a Clean Water Act provision did not prohibit the EPA from issuing variances for pollutants listed as toxic under the statute); EPA v. California ex. rel. State Water Res. Control Bd., 426 U.S. 200, 215 \& n.28, 224-26 \& n.39 (1976) (White, J.) (relying on the legislative history of the Clean Water Act to show a lack of a clear congressional statement that would subject federal facilities to more stringent state permit requirements); Gwaltney of Smithfield v. Chesapeake Bay Found., 484 U.S. 49, $61-63$ (1987) (Marshall, J.) (relying on the Clean Water Act legislative history to show that citizen enforcement actions were authorized only to seek injunctive relief, not for wholly past violations); Train v. Colorado PIRG, 426 U.S. 1, 1 1-23 (1976) (Marshall, J.) (relying on legislative history to show the Clean Water Act compromise in which the Atomic Energy Commission's authority to regulate radioactive effluents from nuclear power plants was not extended to an EPA Administrator as well).

152. See supra Table 5: cumulative findings indicate that liberal Justices rely on legislative history in 162 of 322 majorities, or $50.3 \%$, while conservative Justices rely on legislative history in 69 of 220 majorities, or $31.4 \%$. This difference is highly significant $(t=.0000)$. 
Burger and the Rehnquist/Roberts eras: liberal Justices have relied on legislative history $20 \%$ more often than conservative Justices since 1986 , and the differential was $13 \%$ for the Burger Court. ${ }^{153}$

The liberals' more sympathetic attitude toward legislative history may well signify a difference in judicial beliefs about how best to respect the lawmaking supremacy of Congress. Liberal Justices have tended to regard efforts to discern and apply the intent of key legislative subgroups or individual players in terms of furthering their own constitutional role as junior partner in the lawmaking enterprise. ${ }^{154}$ They believe that the record of such intent can be evaluated in a suitably cautious manner, and therefore that legislative history constitutes relevant and probative evidence of what Congress sought to accomplish. ${ }^{155}$ This approach distinguishes them from Justices Scalia and Thomas, who have often maintained that in order to be properly deferential to Congress's constitutional role as a unified lawmaking body, courts should avoid or minimize reliance on the unenacted intentions expressed by various subgroups within that body. ${ }^{156}$

Scholars in both law and social science have contended that this difference in attitudes must be ideologically driven-that a judge's willingness to draw on legislative background evidence is inevitably influenced by the ideological thrust of the evidence itself. ${ }^{157}$ Our findings on the ideologically neutral aspects of legislative history reliance by liberal

153. In the Burger era, liberal Justices used legislative history in $57.6 \%$ of their majorities (102 of 177) while conservative Justices relied on this resource in $44.2 \%$ of theirs (42 of 95 ), a significant difference $(\mathrm{t}=.0116)$. See also Jorge L. Carro \& Andrew R. Brann, The U.S. Supreme Court and the Use of Legislative Histories: A Statistical Analysis, 22 JURIMETRICS J. 294, 302, 306 (1982) (finding, based on a limited sample, that liberal Justices cite to legislative history substantially more than conservative Justices). In the Rehnquist/Roberts years, liberal Justices invoked legislative history in $41.4 \%$ of their majorities ( 60 of 145 ) while conservative Justices relied on legislative history in $21.6 \%$ of theirs $(27$ of 125$)$, again a significant differential $(t=.0001)$. Although the persistent refusal by Justices Scalia and Thomas to invoke legislative history in majority opinions distinguishes them from all other Justices, three other conservatives (Justices Kennedy, Rehnquist, Powell) rank as the next lowest legislative history users. Of the nine most frequent users, seven are liberals. See generally Brudney \& Ditslear, supra note 52, at 222-23.

154. See e.g., Bank One Chi. v. Midwest Bank \& Trust Co., 516 U.S. 264, 276-77 (1996) (Stevens, J., concurring); W. Va. Univ. Hosps. v. Casey, 499 U.S. 83, 115 (1991) (Stevens, J., dissenting). See generally Stephen Breyer, On the Uses of Legislative History in Interpreting Statutes, 65 S. CAL. L. REV. 845, 853-61 (1992).

155. See generally United States v. Thompson/Center Arms Co., 504 U.S. 505, 516 n.8 (1992) (Souter, J., plurality); Wisconsin Pub. Intervenor v. Mortier, 501 U.S. 597, 610-12 \& n.4 (1991) (White, J.); Train v. Colorado PIRG, 426 U.S. 1, 10 (1976) (Marshall, J.) (quoting from United States v. Am. Trucking Assns. 310 U.S. 534, 543-44 (1940)).

156. See, e.g., Begier v. IRS, 496 U.S. 53, $67-68$ (1990) (Scalia, J., concurring); Pennsylvania v. Union Gas Co., 491 U.S. 1, 29-30 (1989) (Scalia, J., concurring in part and dissenting in part). See also Thunder Basin Coal Co. v. Reich, 510 U.S. 200, 219 (1994) (Scalia and Thomas, JJ., concurring) (rejecting legislative history as superfluous to the interpretive enterprise).

157. See Steven R. Greenberger, Civil Rights and the Politics of Statutory Interpretation, $62 \mathrm{U.}$ Colo. L. REV. 37, 38-51 (1991); Stephen F. Ross, Reaganist Realism Comes to Detroit, 1989 U. ILL. L. REV. 399, 420-25 (1989); Jeffrey A. Segal \& Albert D. Cover, Ideological Values and the Votes of U.S. Supreme Court Justices, 83 AM. POL. SCI. REV. 557, 562 (1989). 
Justices suggest that interpretive philosophy may be a more important factor than previously acknowledged.

Most major bills that become laws undergo considerable changes between introduction and final enactment, due to formal divisions in power between the executive and legislative branches and also to various procedural obstacles within Congress itself. Complex or controversial legislative proposals are usually modified (and occasionally recast) by principal sponsors or managers in order to accommodate the concerns of wavering colleagues or to co-opt segments of the opposition. Because substantial adjustment in text-both before and after a bill's introductionis the rule rather than the exception, committee or floor commentaries that accompany the particular stages of language modification shed light on whatever qualitative changes have taken place. Put succinctly, legislative bargains are a well-accepted feature of American lawmaking, and legislative history may illuminate a bargain's existence or help explain some of its details.

The three doctrinal categories of legislative history invoked by liberal Justices to help explain conservative results may be understood as addressing distinct aspects of this bargaining process. First, legislative history describing and elaborating on employer exemptions or defenses amplifies what is often the earliest form of textual adaptation. Drafters and key initial sponsors incorporate certain protections for employer interests before bill language is even made public, based on discussions among supporters as well as potential opponents or undecideds. Second, legislative record evidence reflecting the existence or contours of subsequent compromises is likely to be found in the post-introduction drafting history. This record of explicit bargains reached during a bill's voyage through Congress indicates when and perhaps why certain employee rights or protections were traded away or not secured after having been advocated by a key group of supporters. Finally, legislative history signifying employee overreach may be viewed as identifying an implicit bargain among the major players. Even on matters where conscious give and take did not occur, deliberative dialogue viewed in context may indicate that Congress never meant to address the issue now raised by employee's counsel, or to go as far as is being advocated.

Our conclusion - that many Justices invoke legislative history to help understand different dimensions of the bargaining process-is at odds with Justice Scalia's critique of such history as deeply unreliable with respect to what Congress considered or intended when it voted on a bill or provision of text. ${ }^{158}$ Professor John Manning has elaborated on Justice Scalia's

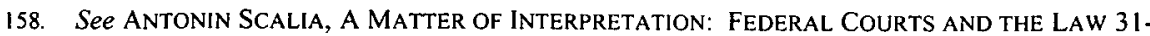
35 (1997). Justice Scalia further maintains that legislative history is intrinsically illegitimate when it is invoked as a basis for imputing intent to Congress. See id. at 35 . Arguments regarding the 
position, arguing that congressional players bargain "in complex and often unknowable ways over a statute's wording," 159 and that because purposivism-which includes reliance on legislative history-cannot plausibly claim to capture the legislative preferences underlying bargainedfor text, it furnishes no special insights into the realities of legislative compromise. ${ }^{160}$

The liberal Justices in our dataset plainly do not embrace this textualist vision. An assessment of their key normative assumption, that legislative history may in appropriate circumstances be imputed to Congress as a whole ${ }^{161}$ is beyond the scope of this Article. In descriptive terms, however, it is worth emphasizing the frequency with which these Justices invoke legislative record evidence to help set limits on the coverage and protections available under pro-employee statutory regimes. The liberals' regular and nuanced reliance on legislative history reflects their belief that this history can help illuminate the dimensions and details of complex legislative deals. More important, these Justices' willingness to follow a legislative history trail leading away from their preferred policy perspectives indicates the principled nature of their interpretive approach.

\section{B. Liberal Justices and Strategic Behavior-A "Scalia Effect"}

In determining that legislative history usage has aligned somewhat more closely with the Justices' ideological preferences since 1986, we presented our findings in Part II based on a division between the Burger era and the Rehnquist/Roberts period. However, when considering shifts in the Justices' approaches to legislative history as an interpretive asset, a more salient development than the ascension of Chief Justice Rehnquist is the arrival of Justice Scalia. While serving as an appellate judge, Scalia had voiced reservations about the reliability of legislative history, ${ }^{162}$ and his

constitutional legitimacy of invoking legislative history are not addressed in this article. See supra note 1 and sources cited therein.

159. John F. Manning, Justice Scalia and the Legislative Process, 62 N.Y.U. ANN. SURV. AM. L. 33,38 (2006).

160. See John F. Manning, What Divides Textualists From Purposivists? 106 ColUM. L. REV. 70, 99, 102-03 (2006).

16i. See, e.g., STEPHEN BREYER, ACTIVE LIBERTY: INTERPRETING OUR DEMOCRATIC CONSTITUTION 87-88 (2005); Bank One Chi. v. Midwest Bank \& Trust Co., 516 U.S. 264, 276-77 (1996) (Stevens, J. concurring); United States v. Thompson/Center Arms Co., 504 U.S. 505,516 n.8 (1992) (Souter, J., plurality). See also Lawrence M. Solan, Private Language, Public Laws: The Central Role of Legislative Intent in Statutory Interpretation, 93 GEO. L.J. 427, 437-53 (2005) (discussing how intent is imputed to legislatures and other group actors on philosophical and linguistic grounds); Lord Hoffmann, The Intolerable Wrestle with Words and Meanings, 114 S.A.L.J. 656, 669 (1997) (explaining that a high profile ministerial explanation of ambiguous text, given on the floor of the House of Commons and from which no member dissents, will at times be the best evidence of what Parliament must have understood it was approving).

162. See Hirschey v. FERC, 777 F.2d 1, 7-8 (D.C. Cir. 1985) (concurring opinion). See also Daniel A. Farber \& Philip P. Frickey, Legislative Intent and Public Choice, 74 VA. L. REV. 423, $442-43$ (1998) 
criticisms generated a reaction from Senators during his confirmation hearings. ${ }^{163}$ Upon becoming a Justice in the 1986 Term, Justice Scalia began to express relentless opposition to colleagues' use of legislative history; he has maintained this outspokenly critical stance to the present day.

\section{Justice Scalia's Line in the Sand}

During his first three terms on the Court, Justice Scalia authored a series of separate opinions--including at least eight concurring in the Court's judgment-in which he expressly attacked or questioned the majority's reliance on legislative history. ${ }^{164}$ In these separate writings, Scalia insisted that the Court should not use legislative history to confirm or reinforce the plain meaning of text, ${ }^{165}$ that legislative history is very likely to be generated for strategic or insincere reasons, ${ }^{166}$ and that in any event it is highly unreliable. ${ }^{167}$ He also asserted on several occasions that courts must discover a statute's purpose or intent only from analyzing the text and not from the vagaries of a legislative record drafted or understood by, at best, small subgroups of members. ${ }^{168}$

Justice Scalia has continued to object strenuously to the use of legislative history throughout his years on the Court. ${ }^{169}$ He often makes a point of declining to join sections of majority analyses that invoke

(discussing Scalia speech critical of legislative history, delivered at a number of law schools during the 1985-86 academic year).

163. See Nomination of Judge Antonin Scalia, to be Associate Justice of the Supreme Court of the United States: Hearings Before the Senate Commission on the Judiciary, 99th Congress (1986) at 65-68 (remarks of Senator Grassley), 106-07 (remarks of Senator Mathias).

164. For separate concurrences, see, e.g., INS v. Cardoza-Fonseca, 480 U.S. 421, $452-53$ (1987); Rose v. Rose, 481 U.S. 619, 642-43 (1987); U.S. v. Taylor, 487 U.S. 326, 344-45 (1988); Blanchard v. Bergeron, 489 U.S. 87, 97-100 (1989); Green v. Bock Laundry Mach. Co., 490 U.S. 504, 527-28 (1989); Pennsylvania v. Union Gas Co., 491 U.S. 1, 29-30 (1989); Jett v. Dallas Indep. Sch. Dist., 491 U.S. 701, 738 (1989); H. J. Inc. v. Nw. Bell Tel. Co., 492 U.S. 229, 252 (1989). See also Edwards v. Aguillard, 482 U.S. 578, 637-38 (1987) (Scalia, J., dissenting) (attacking legislative history reliance); Citicorp Indus. Credit, Inc. v. Brock, 483 U.S. 27, 40 (1987) (Scalia, J., concurring) (rejecting legislative history reliance by embracing portions of majority analysis that do not discuss legislative history). For thoughtful discussion of Justice Scalia's critiques of legislative history usage, see ESKRIDGE ET AL., supra note 27, at 987-90; Farber \& Frickey, supra note 162, at 438-49.

165. See Cardoza-Fonseca, 480 U.S. at 452-53; Taylor, 487 U.S. at 344-45; United States v. Stuart, 489 U.S. 353, 372-73 (1989) (Scalia, J., concurring).

166. See Edwards, 482 U.S. at 638 (Scalia, J., dissenting); Blanchard, 489 U.S. at 99.

167. See Rose, 481 U.S. at 642-43; Blanchard, 489 U.S. at $99 ; N w$. Bell, 492 U.S. at 252.

168. See Bock Laundry, 490 U.S. at 527-28; Union Gas, 491 U.S. at 29-30; Johnson v. Transp. Agency, 480 U.S. 616, 671-72 (1987) (Scalia, J., dissenting).

169. See Intel Corp. v. Advanced Micro Devices, Inc., 542 U.S. 241, 267 (2004) (Scalia, J., concurring); United States v. Estate of Romani, 523 U.S. 517, 535-37 (1998) (Scalia, J., concurring in part and concurring in judgment); Landgraf v. USI Film Products, 511 U.S. 244, 287-88 (1994) (Scalia, J., concurring); Rivers v. Roadway Express, 511 U.S. 298, 314 (1994) (Scalia, J., concurring). 
legislative history, ${ }^{170}$ and he has written separately to chastise newer colleagues for relying on this resource. ${ }^{171}$ Recently, he opposed according differential probative weight to various forms of legislative history, restating his belief that neither legislative commentary of any kind nor the language modifications accompanying a bill's enactment should be admissible in the interpretive enterprise. ${ }^{172}$

Liberal Justices at times have pushed back against the Scalia critique, defending the basic utility of legislative history in their majority decisions $^{173}$ or in separate opinions. ${ }^{174}$ Nonetheless, Justice Scalia's regularly voiced absolutist stance has had an impact over time. Faced with his outspoken opposition (subsequently supported by Justice Thomas), ${ }^{175}$ some Justices seem to have concluded, even if subconsciously, that invoking legislative history in certain settings was not worth the risk of losing support for one's majority opinion or inviting a sharply-worded concurrence. ${ }^{176}$

In examining why liberal Justices' use of legislative history has been somewhat more congruent with their policy preferences after 1986, we

170. See, e.g., Doe v. Chao, 540 U.S. 614, 623 (2004); Dep't of Commerce v. U.S. House of Representatives, 525 U.S. 316, 344 (1999) (Scalia, J., concurring in part); Thunder Basin Coal Co. v. Reich, 510 U.S. 200, 219 (1994); Darby v. Cisneros, 509 U.S. 137, 138 n.* (1993); Reves v. Ernst \& Young, 507 U.S. 170, 172 n.l (1993).

171. See, e.g., Zedner v. United States, 126 S.Ct. 1976, 1990-91 (2006) (Scalia, J., concurring in part and concurring in judgment) (criticizing Justice Alito's reliance on legislative history); United States v. Cleveland Indians Baseball Co., 532 U.S. 200, 220-21 (2001) (Scalia, J., concurring) (critcizing Justice Ginsburg's reliance on legislative history); Bank One Chi. v. Midwest Bank \& Trust Co., 516 U.S. 264, 279-83 (1996) (Scalia, J., concurring) (criticizing Justice Ginsburg's reliance on legislative history); U.S. v. Thompson/Center Arms Co., 504 U.S. 505, 521 (1992) (Scalia, J., concurring) (criticizing Justice Souter's reliance on legislative history).

172. See Hamdan v. Rumsfeld, 126 S.Ct. 2749, 2815-17 (2006) (Scalia, J., dissenting).

173. See, e.g., Conroy v. Aniskoff, 507 U.S. 511,518 n.12 (1993) (Stevens, J.); Thompson/Center Arms Co., 504 U.S. at 516 n.8 (Souter, J., plurality); Wisconsin Pub. Intervenor v. Mortier, 501 U.S. 597,610 n.4 (1991) (White, J.).

174. Bank One Chi., 516 U.S. at 276-79 (Stevens, J., concurring); W. Va. Hosps. v. Casey, 499 U.S. 83, 112-115 (1991) (Stevens, J., dissenting). See also BREYER, supra note 161, at 85-88, 91-95 (defending the legitimacy and utility of legislative history in a non-judicial writing).

175. Justice Thomas has often endorsed Justice Scalia's refusals to join legislative history sections of a majority opinion. See, e.g., Thunder Basin, 510 U.S.at 219; Darby, 509 U.S.at 138 n.*; Reves, 507 U.S. at $172 \mathrm{n} .1$. In addition, Scalia and Thomas have steadfastly refused to invoke legislative history in their majority opinions. In our dataset of labor and employment statutory decisions, the two Justices have authored fifty majority opinions, only one of which relied in any way on legislative history.

176. See, e.g., Michael H. Koby, The Supreme Court's Declining Reliance on Legislative History: The Impact of Justice Scalia's Critique, 36 HARV. J. ON LEGIS. 369, 390-95 (1999) (discussing declining reliance by Justices Stevens and Rehnquist); Brudney \& Ditslear, supra note 52, at 222-24 (discussing declining reliance by Justices White, Stevens, and Marshall). See also Gregory E. Maggs, The Secret Decline of Legislative History: Has Someone Heard a Voice Crying in the Wilderness?, 1994 PUB. INT. L. REv. 57, 64-67, 70-73 (1994) (examining the Court's use of legislative history in the 1992-93 Term and hypothesizing that pressure from Justice Scalia is the most likely explanation for the Court's declining usage); Thomas W. Merrill, Textualism and the Future of the Chevron Doctrine, 72 WASH. U. L.Q. 351, 365 (1994) (discussing the challenge of building majority coalitions in the face of an uncompromising stance from Justices Scalia and Thomas). 
considered the possibility that liberals may simply have become more committed to or adept at employing such history to advance their ideological values. There is, however, no apparent reason to believe that liberal Justices would adopt a more ideological position toward this interpretive resource after Justice Scalia's arrival, especially given our overall findings regarding their majority opinions since 1986. ${ }^{177}$ Instead, we hypothesize a Scalia Effect: that strategic considerations related to retaining Justice Scalia's support may better account for shifts in opinionwriting approaches by liberal members of the Court.

\section{Liberal Justices' Exercise of Legislative History Restraint}

Our assumption is that Justices wish to avoid alienating unnecessarily a colleague who has voted with them in Conference. Given Justice Scalia's relentless objections to legislative history, some liberals may be reluctant to invoke that resource when authoring pro-employer majorities they expect Justice Scalia to join. If these Justices refrain from using legislative history in a sufficient number of pro-employer majorities, their remaining pattern of reliance will acquire a more pro-employee complexion. As we now show, this strategic hypothesis receives considerable support from the proemployer majority opinions of several liberal Justices. Our projected Scalia Effect also is consistent with how often liberal Justices overall have used legislative history when Justice Scalia joins their majorities as opposed to when he does not.

We reported in an earlier article that Justices White and Stevens used legislative history significantly less frequently during the Rehnquist years than they had in the Burger era. ${ }^{178}$ For our purposes, the sharp decline in reliance after 1986 is especially instructive with respect to their proemployer majority opinions. Out of twenty-two conservative majorities joined by Justice Scalia that were authored by liberal Justices and did not invoke legislative history, three-fifths were majorities authored by Justices White or Stevens. ${ }^{179}$

177. See supra Table 3 (reporting that, since 1986, liberals have continued relying on legislative history to help justify the same proportion of conservative as liberal outcomes); supra Tables 4,6 (reporting that liberals since 1986 have favored pro-employee over pro-employer results by a two to one margin in their opinions, whether invoking or ignoring legislative history).

178. See Brudney \& Ditslear, supra note 52, at 223. When omitting these Justices' majority opinions in pure constitutional decisions, and adding decisions from the first Roberts term, Justice White went from using legislative history in $62 \%$ of his majorities (twenty-six of forty-two) during the Burger Court to $18 \%$ (three of seventeen) after 1986 , while Justice Stevens' rate of reliance declined from $48 \%$ (twelve of twenty-five) to $32 \%$ (ten of thirty-one). Justice White's differential is highly significant ( $\mathrm{t}=$ $.0008)$ while the difference for Justice Stevens approaches significance $(t=.099)$.

179. Of the twenty-two pro-employer majorities referred to in text, Justice White authored seven and Justice Stevens six. The remaining nine were written by Justices Breyer (three), Ginsburg (two), Souter (two), Blackmun (one), and Marshall (one). A list of all twenty-two majorities is on file with the authors and may be derived from the tables on Professor Ditslear's website, referred to at supra note 36. 
During the Burger era, sixteen of Justice White's eighteen proemployer majorities relied on legislative history. By contrast, after Justice Scalia's arrival, only one of Justice White's nine pro-employer majorities invoked legislative history, and Justice Scalia joined seven of White's eight pro-employer majorities that did not make use of such history. ${ }^{180}$ The shift for Justice Stevens, while not as dramatic, is still revealing. During the Burger period, Justice Stevens relied on legislative history to help justify seven of his fifteen conservative majorities; after 1986 he invoked this resource to help explain four of his twelve conservative majorities. Justice Scalia joined six of the eight conservative Stevens majorities that did not use legislative history. ${ }^{181}$

Moreover, in two of Justice Stevens' four conservative majorities that did rely on legislative history, Scalia authored concurrences criticizing the majority's use of this resource. ${ }^{182}$

To be sure, a sharply diminished reliance on legislative history in proemployer majorities written after 1986 does not establish that Justices White and Stevens adjusted their reasoning in an effort to retain Justice Scalia's vote. One plausible alternative explanation is that the prevailing litigants before the Court in these cases failed to raise substantial legislative history arguments, and thus the majority authors had no occasion even to consider exercising restraint. We explored this possibility by reviewing the merits briefs filed by the parties, and where applicable the Solicitor General, ${ }^{183}$ for all twenty-two of the pro-employer majorities joined by Justice Scalia. What we found tends to reinforce our hypothesis as to the presence of a Scalia Effect.

In eight of the twenty-two decisions in question, the side that prevailed before the Court did not seriously rely on legislative history in its merits briefs. ${ }^{184}$ In the other fourteen decisions, however, the majority declined to invoke legislative history even though the prevailing party, at times supported by the Solicitor General, relied explicitly and often substantially

180. In the eighth pro-employer majority, Mackey v. Lanier Collection Agency, 486 U.S. 825 (1988), Scalia joined the dissent. Id. at 841 (Kennedy, J., dissenting).

181. In the two pro-employer majorities he did not join, Justice Scalia authored a dissent in De Buono v. NYSA Med. Services Fund, 520 U.S. 806, 816 (1997)), and filed a statement concurring in the judgment in CIR v. Schleier, 515 U.S. 323, 337 (1995)).

182. See Landgraf v. USI Film Products, 511 U.S. 244, $287-88$ (1994) (Scalia, J., concurring); Rivers v. Roadway Express, 511 U.S. 298, 314 (1994). In the other two pro-employer majorities relying on legislative history, Justice Scalia joined one opinion in Laborers Health Trust v. Advanced Lightweight Concrete, 484 U.S. 539 (1988) and joined a dissent in the other, Bartnicki v. Vopper, 532 U.S. 514, 541 (2001).

183. The Solicitor General participated at the merits stage in fourteen of these twenty-two cases, either as a party or amicus.

184. In three of these eight decisions, there were no substantive legislative history arguments at all. In the other five, the losing side relied on legislative history as part of its argument but the winning side did not. We assumed arguendo that in this setting the Court's decision not to rely on legislative history was attributable to the history's failure to support the majority's reasoning rather than to the majority's interest in avoiding reliance. 
on a legislative history argument. Five of these decisions-all five-to-four majorities-were authored by Justice White. ${ }^{185}$ Four decisions-two unanimous and two with dissents filed-were written by Justice Stevens. ${ }^{186}$ Thus, in five of seven White majorities and four of six Stevens majorities favoring employers that Justice Scalia joined, the majority authors did not invoke legislative history, even though the prevailing side argued strongly for such reliance.

Intriguingly, Justice Breyer authored three of the remaining five proemployer majorities that did not invoke legislative history in the face of substantive reliance on this resource by the prevailing party. ${ }^{187}$ The absence of legislative history use in those three decisions lends a distinctly liberal tint to Breyer's relatively small set of majorities invoking legislative history. ${ }^{188}$

It is worth noting that Justices Stevens, Breyer, and White have been outspoken advocates for the reliability of legislative history, explicitly rejecting Justice Scalia's critiques on this score. ${ }^{189}$ Perhaps because their beliefs on the value of legislative history are well established, they see little to be gained by vexing Scalia when he has voted with them, at least when they conclude the majority's result can be adequately justified without

185. See Church of Latter Day Saints v. Amos, 483 U.S. 327 (1987) (petitioner and Solicitor General relied on legislative history argument); Monesson Sw. Ry. Co. v. Morgan, 486 U.S. 330 (1988) (petitioner relied on legislative history argument); Will v. Michigan Dept. of State Police, 491 U.S. 58 (1989) (respondent relied on legislative history argument); Pittsburgh \& Lake Erie R.R. Co. v. Ry. Labor Executives' Assn., 491 U.S. 490 (1989) (petitioner relied on legislative history argument); Chesapeake \& Ohio Ry. Co. v. Schwalb, 493 U.S. 40 (1989) (petitioner relied on legislative history argument). Briefs referenced for all decisions cited in notes 185-87 were obtained and downloaded through Westlaw; they are on file with the authors.

186. See Mullins Coal Co. Inc. v Dir., OWCP, 484 U.S. 135 (1987) (petitioner and Solicitor General as respondent relied on legislative history argument); Golden State Transit Co. v. City of Los Angeles, 493 U.S. 103 (1989) (petitioner relied on legislative history argument); INS v. Nat'l Ctr. for Immigrants' Rights, 502 U.S. 183 (1991) (Solicitor General as petitioner relied on legislative history argument); Collins v. City of Harker Heights, Tex., 503 U.S. 115 (1992) (respondent relied on legislative history argument).

187. See Milwaukee Brewery Workers' Pension Plan v. Jos. Schlitz Brewing Co., 513 U.S. 414 (1995) (respondent relied on legislative history argument); Brown v. Pro Football Inc., 518 U.S. 231 (1996) (respondent and Solicitor General for petitioner relied on legislative history argument); Metro N. Commuter R.R. Co. v. Buckley, 521 U.S. 424 (1997) (petitioner relied on legislative history argument). The final two decisions in which the prevailing party invoked legislative history are Chevron U.S.A. Inc. v. Echazabal, 536 U.S. 73 (2002) (Souter, J.), and Perry v. Thomas, 482 U.S. 483 (1987) (Marshall, J.). Justice Breyer authored a fourth pro-employer majority without legislative history, from which Justice Scalia dissented. See U.S. Airways Inc. v. Barnett, 535 U.S. 391 (2002).

188. See supra Table 5 and accompanying discussion (reporting Justice Breyer's five majorities that rely on legislative history are substantially more liberal than his nine majorities that do not). If even two of the first three majorities cited in note 179 had relied on legislative history, Breyer would then have authored four of seven pro-employee majorities using legislative history and five of seven proemployer majorities invoking such history, making his majority opinions relying on legislative history more conservative or pro-employer than his majorities not relying on that resource.

189. See, e.g., Bank One Chi. v. Midwest Bank \& Trust Co., 516 U.S. 264, 276-79 (1996) (Stevens, J., concurring); Wisconsin Pub. Intervenor v. Mortier, 501 U.S. 597, 610 n. 4 (1991) (White, J.); BREYER, supra note 161 , at $85-88,91-95$. 
having to rely on such history. Accordingly, it seems reasonable to suggest that Justice Breyer-like Justices White and Stevens-may be forgoing legislative history reliance in certain cases as a form of "preemptive accommodation" 190 to retain Justice Scalia's support.

Our findings with respect to these subsets of pro-employer majorities constitute only a preliminary showing of Justice Scalia's impact on certain liberal Justices. The twenty-two majorities without legislative history, for instance, represent one-half of the pro-employer decisions written by liberal Justices since 1986 , but only $15 \%$ of all decisions written by liberal Justices during that period. ${ }^{191}$ Future research attempting to demonstrate this point would require, at a minimum, reviewing briefs from hundreds of additional cases. ${ }^{192}$ There are, however, several further aspects of our dataset that tend to indicate that Justice Scalia's implacable stance on legislative history has influenced patterns of reliance by his liberal colleagues.

First, liberal Justices as a group rely on legislative history less than one-third of the time when Justice Scalia joins their majorities but in nearly three-fifths of the cases where he agrees with the result yet writes a separate concurring opinion. ${ }^{193}$ Justice Scalia's refusal to endorse the majority opinion may not be due to the presence of a legislative history argument, and his joining the majority is unlikely to be a function simply of the majority's silence on legislative history matters. Still, the gap is large enough to suggest that most liberal Justices ${ }^{194}$ view legislative history as an

190. See Forrest Maltzman et. Al., Crafting LAW ON The Supreme Court: The Collegial GAME 96-98 (2000). Maltzman and his co-authors discuss both preemptive and responsive accommodation in the context of substantive differences among the Justices, but preemptive accommodation may also occur for methodological reasons, especially when one Justice's position is presented in such relentlessly uncompromising terms.

191. The liberal Justices have authored 145 majorities from the 1986 Term through the 2005 Term; see supra Table 6 . Justice Scalia has participated in all but one of those cases. See Chao v. Mallard Bay Drilling, Inc, 534 U.S. 235, 236 (2002). Of the 145 decisions, ninety reached pro-employee outcomes, forty-five reached pro-employer outcomes, and ten were indeterminate. See supra Table 3 (identifying cases with pro-employee and pro-employer outcomes).

192. It would be helpful to consider prevailing parties' positions on legislative history reliance in pro-employer decisions not joined by Justice Scalia and in pro-employee decisions that he joined, as well as making some comparisons with party briefs in the period before 1986 . Further, unlike Justices White and Stevens, Justices Blackmun and Brennan did not reduce their legislative history reliance in majorities written after Scalia joined the Court. And unlike Justice Breyer, Justice Souter has invoked legislative history in a number of pro-employer majorities joined by Justice Scalia. The factors influencing different Justices at various times are complex and case-specific, and we do not wish to oversimplify what accounts for decisions about judicial reasoning.

193. Liberal Justices rely on legislative history in $31 \%$ of the eighty-eight majorities that Scalia joins, but in $58 \%$ of the twenty-four majorities where he concurs separately; that difference is significant $(t=.0002)$. The liberals also rely on legislative history in $58 \%$ of the thirty-three majorities from which Justice Scalia dissents in whole or in part.

194. Of the eighty-eight majorities that Justice Scalia joined, five liberal Justices authored ten or more each: Stevens (nineteen), Souter (sixteen), Blackmun (thirteen), White (thirteen), and Ginsburg (ten). Reliance on legislative history ranged from $37-38 \%$ (Blackmun and Souter) to $30 \%$ (Ginsburg) and down to $15-16 \%$ (White and Stevens). Of the twenty-four majorities with which Scalia concurred separately, three liberal Justices authored four or more: Stevens (seven), Blackmun (four), and Marshall 
interpretive asset to be deployed with some caution when Scalia is on their side. That caution is presumably encouraged by the fact that almost half of Scalia's fourteen concurrences in this setting criticize the majority's reliance on legislative history. ${ }^{195}$

Second, looking at pro-employee majorities authored by liberal Justices, legislative history reliance is significantly higher in close cases than in unanimous decisions. ${ }^{196}$ Liberals seem comfortable invoking legislative record evidence in narrow pro-employee majorities where Justice Scalia is unlikely to vote with them, ${ }^{197}$ but they are more reluctant to make use of this resource in the unanimous decisions favoring employees that Scalia does join. ${ }^{198}$ Once again, Justice Scalia's presence in the majority may be subtly discouraging the use of legislative history, even when the prevailing party's legal arguments urge such reliance. ${ }^{199}$

(four). Reliance on legislative history here ranged from $75 \%$ (Blackmun and Marshall) to $57 \%$ (Stevens). Justices Brennan and Breyer each authored a relatively small number of majorities out of the 112 discussed in this footnote-six and nine respectively.

195. See United States v. Cleveland Indians Baseball Co., 532 U.S. 200, 220-21 (2001) (Scalia, J., concurring) (criticizing Ginsburg); Smith v. City of Jackson, Miss., 544 U.S. 228 (2005) (criticizing Stevens); Landgraf v. USI Film Products, 511 U.S. 244, 287-88 (1994) (Scalia, J., concurring) (criticizing Stevens); Rivers v. Roadway Express, 511 U.S. 298, 314 (1994) (criticizing Stevens); Thunder Basin Coal Co. v. Reich, 510 U.S. 200, 219 (1994) (criticizing Blackmun); Citicorp. Indus, Credit, Inc. v. Brock, 483 U.S. 27, 40 (1987) (Scalia, J., concurring) (indirectly criticizing Marshall). From outside our dataset, see also Blanchard v. Bergeson, 489 U.S. 87, 97-100 (1989) (criticizing White); U.S. v. Taylor, 487 U.S. 326, 344-45 (1988) (criticizing Blackmun); INS v. Cardoza-Fonseca, 480 U.S. 421, $452-53$ (1987) (criticizing Stevens); Rose v. Rose, 481 U.S. 619, 642-43 (1987) (criticizing Marshall).

196. The liberal Justices relied on legislative history in $60 \%$ of 15 close decisions reaching proemployee results, but in only $31 \%$ of 54 unanimous decisions favoring employees, a significant difference $(t=.0011)$.

197. Of the nine close pro-employee majorities in which liberal Justices relied on legislative history, Scalia joined two. See Empire Healthchoice Assur., Inc. v. McVeigh, 126 S.Ct. 2121 (2006) (Ginsburg, J.); Loeffler v. Frank, 486 U.S. 549 (1988) (Blackmun, J.). He dissented on the seven other occasions.

198. Greater reluctance does not mean abandonment. As noted earlier, the liberal Justices' $31 \%$ level of reliance on legislative history in these 54 pro-employee unanimous majorities is substantially higher than their conservative colleagues, who invoke legislative history in a mere $7 \%$ of their 28 proemployee unanimous decisions. See supra note 68 and accompanying text. This difference may well reflect the divergence in interpretive philosophy discussed supra at III.A.5.

199. The prevailing party and/or the Solicitor General as supporting amicus relied on legislative history in twenty of the thirty unanimous pro-employee decisions that did not invoke this resource. The twenty decisions were authored by seven different liberal Justices. 
Table 7: Justice Scalia's Behavior in Majority Opinions That Rely and Do Not Rely on Legislative History (LH) $(\mathbf{N}=266)^{200}$

\begin{tabular}{|l|c|c|}
\hline & $\begin{array}{c}\text { Scalia Votes for } \\
\text { Majority Result } \\
(\%)\end{array}$ & $\begin{array}{c}\text { Scalia Joins } \\
\text { Majority Opinion } \\
(\%)\end{array}$ \\
\hline Liberal Majority Relies on LH & $68.3(41)$ & $45.0(27)$ \\
\hline Liberal Majority Does Not Rely on LH & $82.1(69)$ & $71.4(60)$ \\
\hline Conserv. Majority Relies on LH & $92.0(23)$ & $83.3(20)$ \\
\hline Conserv. Majority Does Not Rely on LH & $92.8(90)$ & $81.9(59)$ \\
\hline (Total number of majority opinions for each outcome is in parentheses.) \\
\hline
\end{tabular}

Finally, the results in Table 7, which present Justice Scalia's overall judicial behavior on voting with the majority and joining majority opinions, indicate that liberal Justices have special grounds for concern if they invoke legislative history. When liberal Justices rely on legislative history, Scalia is significantly less likely to join their majority opinions even when he votes on their side. ${ }^{201}$ Moreover, Justice Scalia is also significantly less likely to vote for the majority result when liberal Justices rely on legislative history than when they do not. ${ }^{202}$ Our analyses of the Scalia Effect have focused primarily on whether Justice Scalia is willing to join certain majority opinions, but this finding suggests that the presence of legislative history in a majority opinion written by liberal Justices is also linked to whether Justice Scalia will support the case's outcome. In addition, when liberal Justices rely on legislative history in their majorities, Justice Scalia is significantly less likely to vote for the majority's result or to join the majority's opinion than is true when his fellow conservative Justices rely on legislative history in their majorities. ${ }^{203}$

The findings reported in Table 7 reinforce our conclusions with respect to the subsets of pro-employer and pro-employee majorities authored by liberal Justices discussed above. ${ }^{204}$ At the same time, it is noteworthy that

200. The $\mathbf{N}$ of 266 includes Justice Scalia's twenty-six majority opinions as part of his voting conduct, but these decisions are omitted from analysis of his joining behavior. The total $\mathrm{N}$ excludes four of the 270 cases analyzed in supra Table 6: three cases in which Justice Powell (an older conservative) authored the Court's majority, and one case in which Justice Scalia recused himself.

201. Scalia has voted for the result secured in these decisions $68 \%$ of the time, but has joined the majority opinions authored by liberal Justices only $45 \%$ of the time; the difference is highly significant $(\mathrm{t}=.017)$.

202. Scalia voted with majorities authored by liberal Justices $68 \%$ of the time when those Justices relied on legislative history, but $82 \%$ of the time when they did not invoke that resource; once again, the difference is significant $(t=.035)$.

203. Scalia voted for the majority result in $68 \%$ of the liberals' sixty majorities that used legislative history as opposed to $92 \%$ of the conservatives' twenty-five majorities that relied on this resource, a highly significant difference $(t=.009)$. Similarly, he joined majority opinions relying on legislative history $45 \%$ of the time when liberals were authors, but $83 \%$ of the time when conservatives wrote the majorities $(t=.003)$.

204. See supra text accompanying notes 178-99. 
Justice Scalia's resistance to supporting results or joining opinions, justified in part by legislative history analysis, does not extend to majorities authored by his conservative colleagues. ${ }^{205}$ Indeed, when it comes to majorities authored by these conservatives, Justice Scalia is every bit as likely to vote for a result, or join a majority, that relies on legislative history as one that does not. ${ }^{206}$ In contrast to his intense monitoring of liberal Justices' use of legislative history, Justice Scalia seems inclined to give his conservative colleagues a free ride when they invoke this interpretive resource. We examine one aspect of Scalia's distinctive behavior toward conservativeauthored majorities in the Subsection that follows.

\section{Conservative Justices' Use of Legislative History: A Free Ride?}

Although we focus on how liberal Justices' reliance on legislative history has been affected by Justice Scalia, a brief excursion into usage by other conservative Justices allows for some instructive comparison. In following up on the results from Table 7, we reviewed the eighteen proemployer majorities authored by Justice Scalia's conservative colleagues since 1986 that relied on legislative history. These decisions-authored by Justices Rehnquist, O'Connor, and Kennedy ${ }^{207}$-could give rise to some tension for Scalia: they reach results he is likely to endorse but use a form of reasoning he is known to oppose.

We found that Justice Scalia joined seventeen of these eighteen proemployer majorities; he refused to endorse his conservative colleagues' reliance on legislative history only once in eighteen cases. ${ }^{208}$ That record contrasts markedly with Justice Scalia's position when liberal Justices rely on legislative history to help justify pro-employer outcomes. There are nineteen such decisions written by liberals, of which Scalia joined only ten. Moreover, on the five occasions when Scalia concurred separately without joining the Court opinion, he either criticized the liberal Justice's use of legislative history ${ }^{209}$ or else avoided invoking that history altogether. ${ }^{210}$

205. The conservative colleagues who authored majorities invoking legislative history in Table 7 are Justices O'Connor, Rehnquist, and Kennedy; Justice Thomas has not written a single majority relying on legislative history in our dataset.

206. Thus, Justice Scalia voted for results established in a conservative colleague's majority decision $92 \%$ of the time when the decision relied on legislative history and $93 \%$ of the time when it did not. Similarly, Justice Scalia joined a conservative colleague's majority opinion $83 \%$ of the time when the author relied on legislative history and $82 \%$ of the time when legislative history was not invoked.

207. Justice O'Connor authored nine, Justice Kennedy authored six, and Justice Rehnquist authored four. Justice Thomas has authored no majorities, pro-employer or pro-employee, that rely on legislative history in our dataset.

208. That one instance is Jett v. Dallas Indep. Sch. Dist., 491 U.S. 701, 738 (1989), where he concurred in the judgment and criticized Justice O'Connor's use of legislative history. See supra note 164 and accompanying text.

209. See Landgraf v. USI Film Products, 511 U.S. 244, 287-88 (1994) (criticizing majority opinion by Stevens, J.); Rivers v. Roadway Express, 511 U.S. 298, 314 (1994) (criticizing majority opinion by 
One could infer from this disparity that Justice Scalia is simply less suspicious when conservatives use legislative history than when liberals do, but the reality may be more complex. Of the eighteen pro-employer majority opinions authored by conservatives, six are unanimous and twelve include dissenting opinions. Importantly, eight of the twelve dissents rely on legislative history, so that both majority and dissenting opinions invoke legislative record evidence. Justice Scalia joined the majority in seven of those eight decisions, suggesting that he gives a free ride to Justices Rehnquist, O'Connor, and Kennedy when their use of legislative history either counteracts or anticipates legislative history arguments from proemployee dissenters. ${ }^{211}$ One corollary of this apparent free ride is that majority opinions authored by these three Justices that invoke legislative history are shaded in a conservative direction. The pro-employer tint may help explain why conservative Justices' use of legislative history after 1986 appears more ideologically aligned than was true for older conservatives. ${ }^{212}$

\section{Normative Implications of the Scalia Effect}

Returning our attention to the liberal Justices, the evidence that Justices White, Stevens, and Breyer have exercised legislative history restraint to keep Justice Scalia on board might be understood as an aspect of judicial collegiality. Liberals have hardly abandoned reliance on legislative history, but their targeted forbearance may result in fewer fractured rationales for majority decisions, which may in turn provide clearer rule-of-law guidance to lower courts and practicing attorneys. One might infer as well that such collegial adjustments occur primarily if not exclusively when legislative history performs a supplemental rather than an essential role in the majority's reasoning. Judges and scholars have written persuasively about the ameliorating effects of collegiality on an appellate court, ${ }^{213}$ and this may be an apt illustration.

Stevens, J.); United States v. Cleveland Indians Baseball Co., 532 U.S. 200, 220-21 (2001) (criticizing majority opinion by Ginsburg, J.).

210. See United States v. Burke, 504 U.S. 229, 242-46 (1992) (Blackmun, J., majority); Torres v. Oakland Scavenger Co., 487 U.S. 312, 318-19 (1998) (Marshall, J., majority). Justice Scalia was in dissent in the four remaining majorities authored by liberals that used legislative history to help explain pro-employer results.

211. See Crawford Fitting Co. v. J.T. Gibbons, Inc., 482 U.S. 437 (1987) (Rehnquist, J.); Ansonia Bd. of Educ. v. Philbrook, 479 U.S. 60 (1986) (Rehnquist, J.); Bd. of Trustees v. Garrett, 531 U.S. 356 (2001) (Rehnquist, J); Eastem Enters. v. Apfel, 524 U.S. 498 (1998) (O'Connor, J); Kimel v. Florida Bd. of Regents, 528 U.S. 62 (2000) (O'Connor, J); Alden v. Maine 527 U.S. 706 (1999) (Kennedy, J); Pub. Employees Ret. Sys. of Ohio v. Betts, 492 U.S. 158 (1989) (Kennedy, J).

212. There may well be other reasons for Justice Scalia's more lenient approach to his conservative colleagues. He may trust them more than he trusts the liberals at a doctrinal or ideological level, and therefore be willing to cut them slack in methodological terms. Such an approach would reflect collegial and/or strategic thinking on Scalia's part.

213. See generally Harry T. Edwards, The Effects of Collegiality on Judicial Decisionmaking, 151 U. PA. L. REV. 1639, 1645-52 (2003); MALTZMAN ET. AL. supra note 190, at 149-52; Paul H. Wahlbeck 
It is difficult to know, however, whether accommodation in this instance comes at the cost of offering a less persuasive legal justification for particular decisions. The Court invokes a range of interpretive assets in virtually every majority opinion. Its inclusion of contextual as well as textual analysis, and of historical as well as semantic evidence, contributes to the perception of judicial decisionmaking as rational, principled, and reasonably transparent. The Court's diversity of interpretive resources also effectively invites attorneys to advance complex legal arguments, pushing the Justices toward opinions that are at once objective and nuanced.

In this setting, diminished legislative history usage by the Supreme Court may have broader implications. If the community of practicing lawyers and lower federal court judges perceives that the Justices value legislative history substantially less than they did in the past, this could encourage lawyers and judges to alter their own approaches to legal advocacy and judicial reasoning. ${ }^{214}$ Particularly when the diminished usage is by liberal Justices who have previously expressed their commitment to the legitimacy and value of this traditional resource, the Court may be sending a chilling signal to the legal community.

This possibility-that accommodation of a colleague's intense methodological preferences is depreciating the value attached to an interpretive asset-may also affect future developments on the Court with respect to judicial reasoning. In recent years, Justice Scalia has been adamant in opposing reliance on foreign law to help justify or explain the Court's constitutional decisions. ${ }^{215}$ As was the case with legislative history, Scalia's objections to the use of foreign law as an interpretive resource invoke considerations of legitimacy, reliability, and politicization. ${ }^{216}$ Given some colleagues' apparent response to Scalia's bright-line stance regarding legislative history, one must at least wonder whether the Court's willingness to invoke foreign law sources is destined to follow a similar path.

et. al., Marshalling the Court: Bargaining and Accommodation on the United States Supreme Court, 42 AM. J. POL. SCI. 294, 296-98, 311 -12 (1998).

214. See Maggs, supra note 176 , at 73 (predicting that pressure from Justice Scalia may lead to diminished citation to legislative history by lawyers).

215. See, e.g., Roper v. Simmons, 543 U.S. 551, 622-28 (2005) (Scalia, J. dissenting); Lawrence v. Texas, 539 U.S. 558, 598 (2003) (Scalia, J. dissenting); Atkins v. Virginia, 536 U.S. 304, 347-48 (2002) (Scalia, J. dissenting). See generally Ernest A. Young, Foreign Law and the Denominator Problem, 119 HARV. L. REV. 148 (2005); Louis H. Pollak, Judging Under the Aegis of the Third Article, 51 CASE W. RES. L. REV. 399, 415-18(2001).

216. For Justice Scalia's objections based on legitimacy, see Roper, 543 U.S. at 628; Lawrence, 539 U.S. at 598; Atkins, 536 U.S. at 347-48; and Thompson v. Oklahoma, 487 U.S. 815,869 n.4 (1988) (Scalia, J., dissenting). For Scalia's objections based on reliability and politicization, see Roper, 543 U.S. at 623-24 (reliability); 624-27 (politicization). Indeed, Justice Scalia's lengthy discussion in Roper suggests he is broadening his attacks on foreign law to encompass not simply theoretical concerns about legitimacy, but also practical arguments based on reliability and political manipulation. This more comprehensive assault parallels the development of Scalia's critical approach to legislative history. See Maggs, supra note 176, at 72. 


\section{V. \\ CONCLUSION}

We have attempted to illuminate the nature of the Justices' reliance on legislative history for an ideologically charged, yet intellectually coherent, subset of the Court's docket. It is important to reiterate that workplace law decisions represent a mere one-sixth of the Court's output. ${ }^{217}$ They may also be a somewhat atypical one-sixth, in that labor and civil rights statutes are generally long and complex, with substantial legislative history and a fair amount of evidence that legislative bargains have been important features. ${ }^{218}$ Other statutory decisions, such as the Court's antitrust law or criminal law cases, may turn out not to rely as often or as robustly on legislative history. Antitrust statutes tend to be less detailed and more "common-law like" than laws regulating employer-employee relations, ${ }^{219}$ while federal criminal statutes often involve less deal-making and more unanimity than is typical in the workplace law area. ${ }^{220}$ This variation counsels against insisting on a single theoretical framework for legislative history analysis. Because federal regulatory approaches in other substantive areas of law may warrant different interpretive assumptions, there is reason to question the "one size fits all" approach that has characterized recent debates about the risks and rewards associated with legislative history reliance.

Moreover, our analysis has sought to explore only how legislative history is used to justify and explain majority decisions, not whether it actually accounts for the Justices' substantive positions. We have referred more than once to subconscious elements of judicial reasoning, but we have not attempted to decipher the complex mosaic of motives when the Justices decide to invoke legislative history or any other resource in a particular majority opinion. ${ }^{221}$ Assessing and prioritizing the range of personal values, doctrinal and policy considerations, and principled reasons that contribute to the opinions of individual Justices would require a more pointedly biographical approach.

Notwithstanding these caveats, our account of how the Court invokes this single interpretive resource as part of its reasoning yields valuable

217. See supra text accompanying notes 36-38.

218. See generally Beth M. Henschen, Judicial Use of Legislative History and Intent in Statutory Interpretation, 10 LEGIS. STUD. Q. 353, 366 (1985); SHAPIRO, supra note 81, at 110.

219. See William N. Eskridge Jr. \& John Ferejohn, Super-Statutes, 50 DukE L.J. 1215, 1231-36 (2001) (discussing the Sherman Act); Henschen, supra note 218, at 366-67 (discussing the Sherman Act).

220. See James J. Brudney, Intentionalism's Revival, 44 SAN DIEGo L. REv. 1001, 1017-19 (2007) (discussing Title I of the Anti-Terrorism and Effective Death Penalty Act of 1996, and Title VII of the Violent Crime Control and Law Enforcement Act of 1994).

221. See generally Dan Simon Freedom and Constraint in Adjudication: A Look Through the Lens of Cognitive Psychology, 67 BROOK. L. REv. 1097, $1132-37$ (2002); Dan Simon, A Psychological Model of Judicial Decision Making, 30 RUTGERS L. J. 1, 14-17, 127-137 (1998). 
insights in both descriptive and normative terms. Such insights can help furnish guidelines for lower courts, attorneys, and the legal academy regarding how justifications for doctrinal and policy results are best rendered in future cases. These insights also help to legitimate judicial decision-making, which is important in enhancing the Court's acceptability to the broader public. 222

We concluded that over a thirty-seven year period, liberal Justices have relied on the legislative history of liberal worker-protection statutes in a surprisingly non-ideological fashion. We explained these results by identifying three doctrinally-based justifications that regularly arise in decisions authored by the eight liberal Justices. Each justification relates to the important role played by legislative history in defining or elaborating on congressional bargains that were negotiated in the process of enacting the workplace law statutes and provisions before the Court. At the same time, we have shown how legislative history is a resource that may itself be bartered by the Justices, even if implicitly, to assuage a colleague.

That legislative history may be used in both principled and strategic ways does not distinguish it from other interpretive resources; our prior findings on the Court's use of the canons of construction have revealed a mixed and somewhat cautionary bottom line. ${ }^{223}$ What is noteworthy, however, is that legislative history reliance appears to be far less politicized in practice than its critics have maintained, at least when invoked by liberal Justices in this ideologically focused area of law. Whether the relatively principled uses reported here can support an argument that legislative history is preferable to other interpretive assets currently enjoying a more "neutral" reputation is a question best left for another day.

222. See BAUM, supra note 147, at 97-106, 114-17 (discussing the importance of legal reasoning in establishing judicial reputation among practicing lawyers, legal academics, and judges from other courts); EPSTEIN \& KNIGHT, supra note 22, at $157-77$ (discussing the impact of legitimacy norms in a governing Court's relationship with the general public).

223. See Brudney \& Ditslear, supra note 36, at 103-12. 
